\title{
DIALOGAR CON LA COMPLEJIDAD COTIDIANA. UNA REFUGIADA ESPAÑOLA BAJO LA OCUPACIÓN DE FRANCIA $^{1}$
}

\author{
Dialoguing with daily life complexity. A Spanish refugee woman under \\ occupied France
}

\author{
Alba Martínez Martínez \\ Universidad de Granada / Université Paris VIII-Vincennes-Saint Denis \\ albamar@ugr.es \\ Orcid: 0000-0001-6083-1672
}

Cómo citar este artículo/Citation:

Alba Martínez Martínez, "Dialogar con la complejidad cotidiana. Una refugiada española bajo la ocupación de Francia”, Hispania Nova, 19 (2021): 691 a 732.

DOI: https://doi.org/10.20318/hn.2021.5895

Copyright: (C) HISPANIA NOVA es una revista debidamente registrada, con ISSN 1138-7319 y Depósito Legal M 9472-1998. Los textos publicados están -si no se indica lo contrario- bajo una licencia Reconocimiento-Sin obras derivadas 3.0 España de Creative Commons. Puede copiarlos, distribuirlos y comunicarlos públicamente siempre que cite su autor y la revista y la institución que los publica y no haga con ellos obras derivadas. La licencia completa se puede consultar en: http://creativecommons.org/licenses/by-nd/3.0/es/deed.es

Resumen: Este artículo realiza un recorrido por los años de la Ocupación de Francia a partir del análisis del diario de una joven refugiada española que vivó en zona ocupada y mantuvo una relación estrecha con los ocupantes. Nos proponemos entender cómo se articuló su cotidianidad bajo aquel régimen y en qué medida el género y su condición de refugiada fueron elementos significantes de las relaciones de poder que entabló con los alemanes. Para ello, estructuramos nuestro estudio a partir de cuatro escenarios que recogieron diferentes imágenes, relaciones y formas de entender la Ocupación: el espacio laboral, el hogar y la comunidad, la ciudad de Burdeos y sus lugares de ocio, y la Liberación. Intentamos poner de relieve la agencia femenina para hacer frente a una cotidianidad excepcional, contradictoria y sumamente compleja.

Palabras clave: Ocupación, Mujeres refugiadas, Vida cotidiana, Género, Agencia 
Abstract: This article looks into the the years of the Occupation of France based on the analysis of the diary of a young Spanish refugee woman who lived in the occupied zone and maintained a close relationship with the occupiers. We propose to understand how her daily life was articulated under that regime and to what extent gender and her refugee status were significant elements of the power relations she established with the Germans. To this end, we structured our study around four spaces and moments that brought together different images, relationships and ways of understanding the Occupation: the work space, the home and the community, the city of Bordeaux and its places of leisure, and the Liberation. We tried to highlight women's agency in order to deal with an exceptional, contradictory and extremely complex everyday life.

Keywords: Occupation, Refugee Women, Daily Life, Gender, Agency

\section{INTRODUCCIÓN}

Junio de 1940. Domingo 2

Estoy muy triste, yo creo que no volveremos nunca a España.

Lunes 17

Después de varios meses de combate, Francia se entregó a Alemania y a Italia. Pétain traicionó a su país como hizo Casado con España.

Con apenas 15 años, Conchita Ramírez cruzó la frontera con Francia en febrero de 1939 junto a su madre y cuatro de sus cinco hermanos ${ }^{2}$. Tras pasar por los refugios de civiles de Les Rousses y Maynal (departamento de Jura), en abril del mismo año consiguieron reunirse con su padre en un pueblecito cercano a la ciudad de Burdeos (Gironde), donde este había encontrado trabajo. Entre la añoranza por el hogar perdido, la lucha por la supervivencia y la esperanza en el conflicto internacional, se desarrolló el

\footnotetext{
${ }^{1}$ Este artículo emana de una tesis doctoral en proceso de elaboración que tiene el objetivo de estudiar las experiencias de las mujeres españolas refugiadas en Francia desde una perspectiva de género. La investigación se desarrolla gracias a un contrato predoctoral de Formación de Profesorado Universitario (FPU), del Ministerio de Universidades, Gobierno de España.

${ }^{2}$ Conchita Ramírez, Diario de una niña exiliada, 1939-1947, (Sevilla: Diputación de Sevilla, 2006). El 13 de junio de 2016 tuve la oportunidad de entrevistarla en su casa de Dos Hermanas, Sevilla. Desde aquí, hago explícito mi más sincero agradecimiento a Conchita Ramírez por haber compartido conmigo sus vivencias de aquellos difíciles años.
} 
día a día de Conchita en el exilio. Aquel junio de 1940, ante la Débâcle francesa, la esperanza se desvanecía y la lucha por la supervivencia se hacía más intensa que nunca. La línea de demarcación quiso que Burdeos quedara en manos de los ocupantes alemanes y, con ello, nuevos actores entraron a formar parte de la vida de esta joven refugiada. Su diario, conciso, escueto a veces y aparentemente sencillo, esconde, sin embargo, un diálogo con la complejidad cotidiana; un diálogo con las ambigüedades propias de los contextos excepcionales, como lo fue el de la Ocupación alemana de Francia. Un diálogo que intentaremos desentrañar en las siguientes páginas.

Conchita fue una refugiada del 39. Junto a ella, cerca de medio millón de mujeres y hombres de toda clase y condición social buscaron refugio en Francia ante la inminente caída de Barcelona en manos de las tropas franquistas, produciéndose lo que ha sido conocido como La Retirada ${ }^{3}$. Los estudios sobre el largo exilio republicano que siguió a aquella salida masiva de España son muy abundantes y ricos en enfoques y contenidos $^{4}$. Sin embargo, la atención se ha dirigido preferentemente a las elites exiliadas y, en particular, a los hombres, siendo así sus experiencias, sus voces y sus escritos y, también, sus espacios, los que han dotado de sentido este episodio de nuestro pasado. El exilio republicano de 1939, como otros exilios y migraciones de nuestra historia, se ha conjugado tradicionalmente en masculino, y es que en palabras de Anne Morelli, "la imagen del exiliado/a político/a (como la del militante) se ha construido sobre el modelo de la masculinidad. Su arquetipo es un hombre y la mujer una "anomalía". Durante las últimas décadas, la historiografía, desde la historia de las mujeres y los estudios de género, se ha preocupado por acercarse a los procesos migratorios pretéritos $\mathrm{y}$, en particular, al exilio republicano, a partir de las experiencias

\footnotetext{
${ }^{3}$ Compartimos la problematización que Maëlle Maugendre hace del término de la Retirada -más generalizado en Francia que en España- para hablar del exilio republicano español, al entender que se trata de un concepto militar que hace referencia a la retirada de las tropas armadas. Según Maugendre, el uso del término "muestra hasta qué punto la visión histórica y contemporánea del exilio está generizada y contribuye a invisibilizar a las mujeres", como si ellas no hubieran estado allí. (Maëlle Maugendre, Les réfugiées espagnoles en France (1939-1942): des femmes entre assujettissements et résistances. Tesis doctoral, Université Toulouse le Mirail-Toulouse II, 2013, p. 91)

4 Alguno de los últimos balances historiográficos son los de: Jordi Font i Agullóy Jordi Gaitx Moltó, "L'exili de 1939. Un estat de la qüestió entre dues commemoracions (2009-2014)", Franquisme \& Transició 2, (2014), pp. 231-280; Jorge de Hoyos, "La historiografía sobre refugiados y exiliados políticos en el siglo XX: el caso del exilio republicano español de 1939”, Ayer, vol. 2, (2017), pp. 293305.

5 Anne Morelli, "Exhumer l'histoire des femmes exililées politiques”, en Anne Morelli, (coord.), Femmes exilées politiques. Exhumer leur histoire, (Bruselas: Sextant, 2009), pp. 7-16. Cita en p. 7.
} 
femeninas de los mismos. Esto no solo ha evidenciado que ellas, las mujeres, lejos de ser meras "acompañantes", fueron también "protagonistas" de estos desplazamientos 6 , sino que a su vez ha demostrado que el género es una categoría de análisis indispensable para comprender la especificidad de sus vivencias, de sus relaciones e identidades ${ }^{7}$. Así, los parámetros interpretativos que las han proyectado como sujetos pasivos, desdibujados y ausentes comienzan a cuestionarse, para dejar paso a representaciones más complejas: la de sujetos con capacidad de acción y agencia, sujetos resistentes y resilientes, que con sus escasos medios, contradicciones y ambigüedades hicieron frente al destierro que les había tocado vivir ${ }^{8}$.

Estos cambios de enfoque y perspectiva han obligado tanto a formular nuevos interrogantes a las fuentes, como a incorporar un registro amplio y muy rico de documentación hasta hace poco subestimada: los testimonios orales, las memorias, la correspondencia y, también, los diarios ${ }^{9}$. Las fuentes de esta naturaleza -sin perder de

\footnotetext{
${ }^{6}$ Mónica Moreno, “Las exiliadas, de acompañantes a protagonistas". Ayer, 81, (2011), pp. 265-281.

${ }^{7}$ Philippe Rygiel, "Du genre de l'exil", Le Mouvement Social, 4, (2008), p. 3-8. Disponible en línea: https://www.cairn.info/revue-le-mouvement-social-2008-4-page-3.htm .

${ }^{8}$ Sobre el exilio español de 1939, véase: Rose Duroux, "Historia y desmemoria: prácticas culturales en los refugios de mujeres españolas en Francia, 1939-1940”, Melanges Louis Cardillac, Zaghouan, 1995, FTERSI; Alicia Alted, "El exilio republicano español de 1939 desde una perspectiva de las mujeres". Arenal. 4-2, (1997), pp. 223-238; Pilar Domínguez, De ciudadanas a exiliadas. Un estudio sobre las republicanas españolas en México, (Madrid: Cinca, 2009); Mercedes Yusta, Madres coraje contra Franco, Madrid: Cátedra, 2009; Mónica Moreno, "L'exil au féminin: Républicaines et antifranquistes en France", en Bruno Vargas (coord.), La Seconde Républicque Espagnole en exil en France (1939-1977), Presses Universitaires de Champollion, Albi, 2008, pp. 163-181; Maëlle Maugendre, Femmes en exil. Les refugiées espagnoles en France, 1939-1942, Tours: Presses universitaires François-Rabelais, 2019; Alba Martínez, ¿"Pour quelles raisons avez vous quitté l'Espagne? De represaliadas a refugiadas políticas en la Francia de los años 40 y 50”, Historia Contemporánea, 59, (2019), pp. 277-314; Diego Gaspar Celaya, "Combatir sin armas. Mujeres españolas al servicio de la Francia Combatiente, 1940-1945", Historia Social, 97, 2020, pp. 135-156.
}

Sobre otros exilios: Sylvie Aprile, "De l'exilé à l'exilée: une histoire sexuée de la proscription politique Outre-Manche et Outre-Atlantique sous le Second Empire", Le Mouvement Social, 4, (2008), pp. 27-38; Delphine Díaz, "Femmes en exil, femmes réfugiées dans la France du premier XIX siécle. Vers la difficile reconnaissance d'un statut", en Nicolas Beaupré y Karine Rance (dirs.), Arrachés et Déplacés. Réfugiés politiques, prisonniers de guerre et déportés, 1789-1918, Presses Universitaires Blaise Pascal, 2016, pp. 47-62.

9 Algunos estudios que han incorporado estas fuentes prestando especial atención a los exiliados "de a pie" son los de: Alicia Alted, La voz de los vencidos. El exilio republicano de 1939, (Madrid: Madrid, 2005); Pilar Domínguez, "Ellas nos cuentan. Los relatos de vida en la historia del exilio republicano en México" en Miren Llona, Entreverse. Teoría y metodología práctica de las fuentes orales, (Bilbao: Universidad de País Vasco, 2012), pp. 161-186; Paula Simón: "Los campos de concentración franceses contados por las mujeres: aportes para la reflexión sobre la narrativa testimonial femenina", Laberintos, n.14, (2012), pp. 151-165; Guadalupe Adámez, Gritos de papel. Las cartas de súplica del exilio español (1936-1945), (Granada: Comares, 2017); Alba Martínez, "Las mujeres recuerdan. Género y memoria sobre exilio republicano en Francia, 1939-1978”, Arenal. vol. 26, n. 2, (2019), pp. 367-398. 
vista las diferencias que existen entre ellas- cobran especial relevancia por varias razones. De un lado porque ofrecen la posibilidad de escuchar y leer a los $\sin \operatorname{voz}^{10}$, a aquellos que difícilmente aparecen representados en los documentos oficiales. De ahí que se hayan convertido en fuentes imprescindibles para la historia de gente corriente y, en particular, para la historia de las mujeres. De otro lado, han resultado cruciales para adentrarse en la historia de la vida cotidiana, desvelar y comprender las lógicas del día a día y las diferentes formas en que son asimiladas por las gentes "de a pie". En palabras de Luisa Passerini, permiten "afrontar el estudio de los seres humanos no solo respecto al poder político, las estructuras económicas [o] las organizaciones sociales; sino también respecto a los comportamientos interpersonales, los mecanismos psicológicos y cognoscitivos, los intereses, las ideas y las imágenes que están en las mentes de los individuos" ${ }^{\prime 1}$. Por ello, y en último lugar, también se han revelado especialmente útiles para estudiar los procesos de construcción de identidades y subjetividades que, siempre inestables y fluctuantes, encuentran en estos soportes, auténticos dispositivos de invocación y negociación; dispositivos idóneos donde plasmar, en palabras de Joan W. Scott, los "ecos de la fantasía"12.

Nuestra fuente principal, el diario de Conchita, es por todo lo anterior una documentación muy rica $^{13}$. Nos permite adentrarnos en la vida cotidiana de una refugiada "de a pie" y, además, a diferencia de los ejercicios retrospectivos que se materializan en memorias y testimonios orales, nos posibilita hacerlo desde la inmediatez de sus vivencias que quedaron recogidas a las pocas horas de ser

\footnotetext{
${ }^{10}$ Mercedes Vilanova ha subrayado que no se trata de "dar la palabra" a aquellos que no la tienen sino de escuchar a "las mayorías invisibles" y hacerlas formar parte de la historia (Citado en: Thébaud, Françoise Thébaud y Geneviève Dermenjian, "Introduction" en Françoise Thébaud y Geneviève Dermenjian (dirs.), Quand les femmes témoignent. Histoire orale, histoire des femmes, memoire des femmes, Publisud, 2009, p. 13)

${ }^{11}$ Luisa Passerini, "Sull'utilitá e il danno delle fonti orali per la storia" en Luisa Passerini (coord.), Storia orale. Vita quotidiana e cultura materiale delle classi subalterne, Torino: Rosenberg \& Sellier, 1978, p. 9.

${ }^{12}$ Para Scott la identidad no es sino una "fantasía" que "extrae coherencia de la confusión y reduce la multiplicidad a la singularidad". El "eco", por su parte, sería la repetición alterada, negociada y cambiante que le proporciona a la identidad una apariencia de estabilidad y naturalidad. (Joan W. Scott, "El eco de la fantasía: la historia y la construcción de la identidad", Ayer, 62, (2006), pp. 111-138. La cita en la página 119)

${ }^{13}$ A lo largo del artículo nos apoyaremos, cuando lo consideremos oportuno, en la entrevista realizada a la autora del diario. Esta se centró especialmente en los años que no quedaron recogidos en el escrito de Conchita Ramírez, esto es, los posteriores a la Ocupación, razón por la cual su uso para este estudio será puntual.
} 
experimentadas ${ }^{14}$. Subraya Philippe Lejeune que "el valor del diario es el de ser una huella", "una serie de huellas fechadas" 15 . Dejamos así de lado la distorsión del tiempo y de la memoria, al igual que la influencia que ejercen los relatos mitificados con posterioridad, para transitar por las palabras de una joven refugiada española que sintió, padeció, se inquietó y se emocionó en la Francia de los convulsos años $40^{16}$. Pero además de ser una fuente muy rica por su naturaleza, lo es también por el contexto que abarca. La mayoría de los testimonios de refugiadas españolas que han llegado hasta nosotros se acercan a estos años desde la experiencia del internamiento en los campos y refugios, así como desde la Resistencia a la ocupación alemana, pero muy difícilmente encontramos egodocumentos que recojan la convivencia estrecha con la misma ${ }^{17}$. Por su excepcionalidad y los interrogantes que este artículo se plantea consideramos oportuno, tanto desde el punto de vista teórico como metodológico, un análisis particular del mismo, pues supone una aportación de interés para los estudios sobre el exilio republicano y para los relativos a la ocupación de Francia.

Los últimos estudios que, desde la historia social y también de género, se han acercado a los años de Ocupación en el hexágono, han evidenciado la complejidad de lo acontecido, han problematizado el relato heroico de la Resistencia francesa, han subrayado las relaciones y espacios generizados que se construyeron y han superado las aproximaciones dicotómicas. Como ha señalado Robert Gildea, "las relaciones entre franceses y alemanes bajo la Ocupación no pueden reducirse a opresión alemana frente a patriotismo francés. A pesar de la evidente desigualdad de poder entre las partes, las interacciones entre ellos fueron multifacéticas, sutiles y complejas" ${ }^{18}$. Aunque Conchita

\footnotetext{
${ }^{14}$ Sobre el uso que los historiadores han hecho del diario como fuente, véase: Penny Summerfield, Histories of the Self. Personal Narratives and Historical Practice, New York, Routledge, 2019. Especialmente el capítulo III, "Historians and the diary".

${ }^{15}$ Philippe Lejeune: "Un journal à soi: historia de una práctica", Intramuros, (2005), p. 12.

${ }^{16}$ Asumimos, no obstante, que trabajamos sobre la versión publicada del diario, por lo que es posible que se suprimieran o modificaran partes del mismo. No hemos podido conocer su proceso de edición y somos conscientes de que, en palabras de Lejeune, "el diario no está hecho para ser publicado", lo que puede suponer una "degradación" y un "empobrecimiento" del mismo. (Philippe Lejeune: "Un journal à soi...op. cit., p. 13) Sin embargo, pensamos que ello no invalida la pertinencia de su análisis, ni desacredita las aportaciones que hace para el conocimiento de la vida cotidiana de estos años.

${ }^{17}$ Véase: Paula Simón: "Los campos de concentración franceses contados por las mujeres...op. cit. $\mathrm{M}^{\mathrm{a}}$ Fernanda Mancebo: "Las mujeres españolas en la Resistencia francesa", Espacio, Tiempo y Forma, v. 9, 1996, pp. 239-256.

${ }^{18}$ Desde esta perspectiva no pretendemos, en ningún caso, atenuar la dureza de la Ocupación y del Tercer Reich. La cita en: Robert Gildea, Marianne in Chains. In Search of the German Occupation 1940-1945,
} 
Ramírez fue una refugiada española, no una francesa, sus vivencias pueden enmarcarse a la perfección en lo señalado por el historiador inglés en su Marianne in chains. En su narración, lo bueno y lo malo, enemigos y amigos, colaboradores y resistentes, no aparecen sino como representaciones porosas e inestables que tropiezan incesantemente con su cotidianeidad. Su escrito nos ayuda así a transitar el camino trazado por estos últimos planteamientos.

Conchita Ramírez nació en Melilla durante la guerra de Marruecos. Su padre era militar y ello los hizo cambiar a menudo de residencia. Cuando tenía dos años, la familia se trasladó a Córdoba, después a Cádiz y a Madrid, donde les sorprendió el estallido de la guerra civil. Durante la misma, su padre, leal a la República, fue ascendido a Teniente Coronel del Ejército, y ello les obligó a trasladar su residencia a Valencia primero y a Barcelona después. Conchita comenzó a escribir su diario en agosto de 1936 a la edad de 12 años y, con enorme lucidez, recorrió la guerra civil, el cruce de la frontera, su internamiento en refugios, la ocupación alemana de Francia, la Liberación y el retorno a la "normalidad" que tanto anhelaban desde el estallido de la contienda. Dejó de escribir en 1952 para decidir publicar su escrito en 2006, convirtiéndose en "agente de la memoria" ${ }^{19}$ y escribiéndose en el relato escenificado para escribirse así en la historia ${ }^{20}$.

Nos proponemos acercarnos a las vivencias de Conchita en Francia, y en particular a las acontecidas durante los años de la Ocupación (1940-1944), como un ejercicio de microhistoria que busca entender el contexto en que una experiencia así,

(London: Macmillian, 2002), p. 67. Traducción propia de este y los siguientes extractos. Otros estudios en ese sentido son los de: Richard Vinen, The Unfree French. Life under the Occupation, (London: Penguin Books, 2006). Nicole Dombrowski Risser, France under Fire. German Invasion, Civilian Fight, and Family Survival during World War II, (New York: Cambridge University Press, 2012). En particular, sobre las mujeres: Anne Sebba, Les parisiennes. How the Women of Paris, Lived, Loved and Died in the 1940s, (Londres: Weidenfeld \& Nicolson, 2016). Dominique Veillon, "La vie quotidienne des femmes sous l'occupation" en Évelyn Molin-Rotureau (dir.): 1939-1945: combats de femmes. Françaises et Allemandes, les oubliées de l'histoire, Autrement, (Paris: 2001), pp. 32-48. Paula Schwartz, "The politics of food and gender in occupied Paris", Modern \& Contemporary France, Vol. 7, n 1 (1999), pp. 35-45. Hanna Diamond, Women and the Second World War in France, 1939-1948. Choices and Constraints, (New York: Routledge, 2013).

${ }^{19}$ Irene Murillo, "Dignidad, supervivencia y luto. Agencia y resistencias de mujeres aragonesas de guerra y posguerra", en Mercedes Yusta y Ignacio Peiró (Coords.), Heterodoxas, guerrilleras y ciudadanas. Resistencias femeninas en la España moderna y contemporánea. (Madrid: Institución Fernando el Católico, 2015), pp. 149-174, p. 151.

${ }^{20}$ Joan W. Scott, "El eco de la fantasía...op. cit., p. 120. 
con sus interacciones específicas, fue posible. Atendemos a los presupuestos teóricos de la historia de género, de la vida cotidiana y prestamos especial atención a la agencia y las resistencias "disfrazadas" e "implícitas" que, conscientemente a veces e inconscientemente otras muchas, le permitieron sobrevivir en aquel contexto de excepción ${ }^{21}$. Desde estas perspectivas, nuestro objetivo es el de comprender cómo se articuló la cotidianidad de esta joven refugiada bajo la Ocupación; en qué medida la experiencia de la Ocupación marcó su proceso de construcción identitaria como "refugiada española"; y hasta qué punto el género y su condición de extranjera fueron elementos significantes de las relaciones de poder que se entablaron entre el ocupante y el ocupado.

Nuestra hipótesis es que el diario de nuestra protagonista evidencia una cotidianidad bajo la Ocupación teñida de grises. Una cotidianidad compleja, contradictoria y ambivalente, marcada por unas relaciones de poder que tuvieron en el género uno de sus elementos constitutivos. Una cotidianidad que, de un lado, contribuye a definir su identidad como refugiada y, de otro, nos muestra a una joven exiliada "de a pie" que, lejos de ser una mera receptora de las lógicas de aquel régimen, gestionó con las herramientas que tuvo a su alcance las condiciones de opresión que la subordinaron; asumiéndolas en unas ocasiones, transgrediéndolas y contestándolas en otras muchas, lo que en definitiva nos presenta a un sujeto político en su "doble naturaleza" de víctima, pero también de agente ${ }^{22}$.

Estructuramos nuestro estudio en cuatro partes que responden, a nuestro entender, a los cuatro escenarios espaciales y temporales, pero también emocionales, por los que transitó Conchita durante los años de Ocupación. Estos son el trabajo, el hogar y

\footnotetext{
${ }^{21}$ Seguimos particularmente algunos de los siguientes planteamientos y recorridos teóricos. Sobre género: Joan W. Scott, Género e Historia, (México D.F.: UACM, 2008). Sobre "resistencias cotidianas": James C. Scott, Los dominados y el arte de la resistencia, (México D.F.: Txalaparta, 2003); Sobre la historia de la vida cotidiana: Paul Steege et at, "The History of Everyday Life: A Second Chapter", The Journal of Modern History, vol. 80, n. 2, (2008), pp. 358-378; Francisco A. Ortega, "Rehabitar la cotidianidad", en Francisco A. Ortega (ed.), Veena Das. Sujetos de dolor, agentes de dignidad, (Bogotá: Universidad Nacional de Colombia, 2008), pp. 15-38; Claudio Hernández Burgos, "Tiempo de experiencias: el retorno de la Alltagsgeschichte y el estudio de las dictaduras de entreguerras", Ayer, 113, (2019), pp. 303-317; Sobre agencia y género: Lois Mcnay, Gender and Agency. Reconfiguring th Subject in Feminist and Social Theory, (Cambridge: Polity Press, 2000); Saba Mahmood, "Teoría feminista y agente social dócil: algunas reflexiones sobre el renacimiento islámico en Egipto" en Liliana Suárez Navaz y Rosalva Aída Hernández (eds.), Descolonizando el feminismo. Teorías y prácticas desde los márgenes, (Madrid: Cátedra, 2008), pp. 165-222.

${ }^{22}$ Irene MURILLO, “Dignidad, supervivencia y luto... op. cit., p. 158.
} 
la comunidad, la calle y los momentos de ocio, y por último y a modo de apéndice, la Liberación y los meses que la siguieron. En ellos imperaron relaciones, imágenes y dinámicas diversas que nuestra protagonista negoció de formas plurales y que no hacen sino evidenciar el grado de complejidad que pudo llegar a poseer un contexto como el que nos concierne al ser experimentado desde abajo y por una joven refugiada española.

\section{¿TRABAJAR PARA EL ENEMIGO?}

El 8 de diciembre de 1940, tras seis meses de ocupación, Conchita recogió en su diario que ante la falta de posibilidades laborales que los franceses ofrecían a los exiliados, su padre se había "decidido a pedir trabajo a los alemanes" ${ }^{23}$. Dos meses después se decidiría ella. Eran los dos únicos salarios que entraban en un hogar de seis habitantes y en un contexto de enorme escasez. Su familia tuvo una situación relativamente excepcional y "privilegiada" en comparación a la que padecieron las demás familias de refugiados españoles durante los primeros años de exilio. Como los demás, al llegar a Francia fueron alejados del padre de familia a causa de una política de acogida a todas luces generizada que internó de un lado a los hombres en edad de llevar armas y de otro a las mujeres, los niños y los ancianos, lo que provocó la separación traumática de miles de familias españolas ${ }^{24}$. Sin embargo, a los dos meses de cruzar la frontera, cuando la mayoría de refugiados seguían internados o habían sido repatriados, el padre de Conchita consiguió una autorización ${ }^{25}$ para reunirse con su familia en un pequeño pueblo cercano a la ciudad de Burdeos, llamado Chambery ${ }^{26}$. Allí comenzaron una nueva vida, aunque siempre pensada desde la provisionalidad pues en aquellos primeros momentos mantenían la esperanza de volver a España pronto o en su defecto reemigrar a Amércia Latina, proyectos que se verían finalmente frustrados. A pesar del

\footnotetext{
${ }^{23}$ Conchita Ramírez, Diario de una niña exiliada...op. cit., p. 66.

${ }^{24}$ Maëlle Maugendre, Femmes en exil...op. cit., p. 29.

25 El padre de Conchita, como alto mando del Ejército republicano, recibió ayudas del Servicio de Evacuación de los Refugiados Españoles (SERE), con cuyos miembros mantuvo una estrecha relación. Parece probable que ello facilitara la expedición de la autorización de reencuentro familiar en una fecha tan temprana.

${ }^{26}$ Conchita Ramírez nos dice que el pueblo fue construido por españoles que le pusieron de nombre Chambery. Sobre la presencia de españoles en él no tenemos más referencias que las aportadas por la entrevistada. En la actualidad se trata de un barrio de Villenave d'Ornon, localidad francesa perteneciente a la Comunidad Urbana de Burdeos. Agradecemos a Janine Molina (Asociación de memoria histórica "Ay Carmela") las aclaraciones al respecto.
} 
reencuentro familiar, la precariedad, las necesidades y la inestabilidad laboral reinaron en el seno del hogar. Así, al igual que otras muchas refugiadas españolas, Conchita, siendo la mayor de los cuatro hermanos que habían salido a Francia -la mayor de todos se quedó en España-, se introdujo en el mundo laboral, desempeñando por vez primera un trabajo remunerado ${ }^{27}$.

Comenzó acompañando a su padre a la vendimia, hasta que en septiembre de 1940 consiguió un empleo doméstico, cuidando a los cinco niños de una familia francesa -los señores Palmié-. Esta experiencia laboral, inmediatamente previa a la que después tuvo con los alemanes, fue breve - entre septiembre de 1940 y enero de 1941pero suficiente para constatar y adquirir conciencia de las enormes desigualdades sociales que imperaban. Penetrar en el seno de una familia acomodada siendo una refugiada española que, además, había sufrido una importante pérdida de estatus social con su llegada al exilio, le permitió comparar realidades y entristecerse con ellas:

Estoy contenta de ocuparme de los niños, juego con ellos y les cuento historias, pero son muy traviesos, sobre todo en la mesa, no quieren comer (...) sobre todo Jean René, dice que masticar le cansa. Entonces pienso en mis hermanos que ya quisieran cansarse comiendo. ¿Por qué tanta injusticia? Unos tanto y otros tan poco. (...) Cuando les servía pensaba en mi situación doméstica. Tuve tanta pena que lloré. ${ }^{28}$

$\mathrm{Su}$ trabajo en aquella casa duró poco porque Conchita no toleró que la explotaran. El incidente que aceleró su despido tuvo que ver con las cartillas de racionamiento que desde hacía poco tiempo limitaban la alimentación de cada familia. Aunque ella almorzaba en el hogar de los Palmiè, no desayunaba ni cenaba allí, por lo que entendía que no debía entregarle a la familia los tickets correspondientes a estas comidas. Ante la insistencia de los Palmiè, Conchita "se despidió" y decidió entonces recurrir a los empleos ofertados por los alemanes. La economía francesa, que había quedado muy mermada a causa de la derrota, generó casi un millón de desempleados

\footnotetext{
${ }^{27}$ Sobre los primeros trabajos desempeñados por las refugiadas españolas en Francia, véase: Maëlle Maugendre, Femmes en exil...op. cit., pp. 296 en adelante. Sobre la relación entre las españolas -exiliadas y emigrantes- en Francia (1939-1975) y el trabajo formal e informal, véase: Rocío Negrete, "No tenía pretensiones, solo quería trabajar. Españolas en Francia, servicio doméstico y empleo informal (19391975)", Cahiers de civilisation espagnole contemporaine, 21, (2008) [En línea] Publicado el 13 enero 2019, consultado el 27 enero 2019. URL: http:// journals.openedition.org/ccec/7789.

${ }^{28}$ Conchita Ramírez, Diario de una niña exiliada...op. cit., p. 65.
} 
que, como Conchita y su padre, aprovecharon la contratación laboral impulsada por el régimen de Ocupación ${ }^{29}$. Sus recuerdos, casi ochenta años después, evidencian, además, la operatividad de su condición de extranjeros como un eje de opresión notable en su relación laboral con los franceses. Discriminación que, sin embargo, habría permanecido inactiva -al menos en lo que a ella respecta- en su interacción con los ocupantes; vencedores, pero, también, extranjeros: "mi padre y yo gracias a los alemanes pudimos vivir un poquito mejor, eh, porque los franceses decían que mientras que hubiera un parado en Francia, no se cogía a un español, así que..."30. En cualquier caso, para ella como para otros muchos refugiados y franceses, el espacio laboral se convirtió así en el epicentro de la "cohabitación” directa con los recién llegados ${ }^{31}$.

Los empleos desempeñados por Conchita fueron precarios y agotadores. Primero trabajó en un hospital militar limpiando largas, anchas y sucias galerías, después en otro, donde además de limpiar, servía a los enfermos y, finalmente, gracias a la experiencia acumulada y a recibir algunos conocimientos básicos, ejerció como enfermera. Para lograr un dinero extra con el que contribuir un poco más a la economía

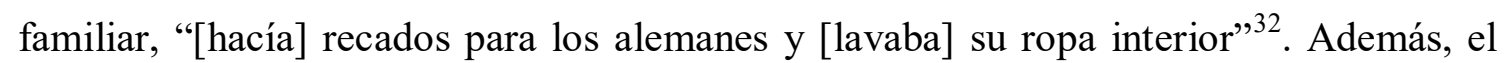
trabajo en el hospital le posibilitaba "sacar comida a escondidas", aunque a veces "[sufriera] la humillación de ser registrada a la salida" "33. Este "complemento" era vital en aquel escenario de carestía y desabastecimiento alimenticio. De hecho, al poco tiempo de empezar a trabajar para los alemanes, se le ofreció un contrato en una oficina de correos en la misma ciudad de Burdeos que, sin embargo, terminó rechazando porque de lo contrario habría perdido la oportunidad de seguir llevando comida a casa. Y es que las preocupaciones pragmáticas por sobrevivir se situaron, en no pocas ocasiones, por encima de las lealtades políticas o las diferencias con otros grupos ${ }^{34}$.

\footnotetext{
${ }^{29}$ Richard Vinen, The Unfree French...op. cit., p. 116.

${ }^{30}$ Entrevista realizada por Alba Martínez a Conchita Ramírez, 13-06-2016, Dos Hermanas, Sevilla.

${ }^{31}$ Robert Gildea, Marianne in Chains..., p. 65. Julian Jackson, France. The Dark Years, 1940-1944, New York: Oxford University Press, 2001, p. 336.

${ }^{32}$ Conchita Ramírez, Diario de una niña exiliada...op. cit., p. 73.

${ }^{33}$ Ibid, pp. 73 y 77.

34 Shannon L. Fogg, The Politics of Everyday Life in Vichy France. Foreigners, Undesirables and Strangers, Nueva York: Cambridge University Press, 2009, p. 18.
} 
Conchita decidió así trabajar para el ocupante, pero, a su vez, decidió exponerse todos los días a ser castigada por vulnerar la legalidad. Una decisión y una práctica que, lejos de evidenciar docilidad y sumisión, comprende el ámbito de lo que James C. Scott llamó "la infrapolítica de los desvalidos" 35 . Una acción no coordinada ni organizada más que individualmente, cuya causa era la mera lucha por la supervivencia bajo un régimen de ocupación que dejaba pocas alternativas a las clases subalternas. Por ello, para Conchita y su familia, estos pequeños hurtos cotidianos eran considerados actos legítimos y morales que, más allá de cometerse contra un "enemigo reconocido", eran una respuesta lógica al hambre, la escasez y a la voluntad de defender la subsistencia familiar en condiciones tan extremas ${ }^{36}$. Condiciones que, además de acentuar su capacidad de acción y agencia, agudizaron su conciencia social y su sentido de la justicia:

He llorado muchas veces y he meditado. ¿Cómo podía creer en un Dios? ¿Por qué son siempre los malos los que triunfan? (...) Mentira, todo era engaño y desde entonces perdi la fe que mis padres me habian inculcado. Desde entonces comprendi (...) que no existen milagros ni justicia para la gente honrada y que son los poderosos quienes dominan todo",37.

¿Cómo fue la relación de Conchita con los alemanes? ¿Quiénes eran aquellos "poderosos que lo dominan todo"? ¿Trabajó realmente para el "enemigo"? Aunque siempre definió el trabajo y, especialmente, el trato de los alemanes hacia su padre como "humillante" 38 , su experiencia relacional en el espacio laboral fue, sin embargo, mucho menos férrea, mostrándose en general distendida e, incluso, agradable. A nuestro entender, tres elementos articularon su relación con los ocupantes: la cordialidad y la profesionalidad, las conversaciones en torno a experiencias de guerra y política, y sobre todo, la sexualidad, el amor y el cortejo. Por este último aspecto, que fue uno de los

\footnotetext{
${ }^{35}$ James C. Scott, Los dominados y el arte de la resistencia ... op. cit., pp. 276-277.

36 Tomamos estas ideas de los estudios realizados para el contexto de la posguerra franquista. Especialmente: Óscar Rodríguez Barreira, "Lazarillos del caudillo. El hurto como arma de los débiles frente a la autarquía franquista", Historia Social, 72, (2012), pp. 65-87; Miguel Ángel DEL Arco Blanco, Hambre de siglos. Mundo rural y apoyos sociales del franquismo en Andalucia Oriental (1936-1951), (Granada: Comares, 2007). Gloria Román, Delinquir o morir. El pequeño estraperlo en la Granada de posguerra. (Granada: Comares, 2015).

${ }^{37}$ Conchita Ramírez, Diario de una niña exiliada...op. cit., p. 67.

${ }^{38}$ Ibid., pp. 73 y 79.
} 
principales, y por las diferencias que encontramos entre la experiencia de su padre y la suya, entendemos que el género fue un claro significante de los vínculos de poder que se generaron entre los ocupantes y los ocupados.

Todo ello distorsionó notablemente sus imágenes preconcebidas y fijas del "enemigo", del "bueno" y del "malo", para, desde la cercanía, dejar paso a la empatía y la humanización. El martes 8 de abril de 1941 recogió en su diario: "Hay un cirujano alemán llamado Leitterman, que cada vez que me ve intenta hablarme, pero yo le esquivo, me asustan sus ojos cuando me miran" 39 . El lunes 28 anotó contrariada: "El doctor Leitterman me ha dicho que si quiero ser enfermera me ayudará, y aprendí a tomar el pulso, la manera de coger los instrumentos, la tensión, todo esto me entusiasmó, pero temía que no fueran desinteresadas sus lecciones" ${ }^{* 4}$. Como ha sido estudiado, la cohabitación tuvo tanto que ver con el dinero como con el sexo, y es que muchos alemanes "llegaron como turistas sexuales y gastronómicos, tanto como soldados" 41 , por lo que Conchita se mantuvo siempre alerta ante la menor proposición indebida. Sin embargo, un mes después, tras haber trabajado y aprendido con él, escribió: "El doctor Leitterman ha venido a despedirse, se marcha al frente ruso. Lo siento mucho, ha sido muy bueno y respetuoso conmigo. (...) dicen que es el mejor cirujano, hace milagros y además es muy humano" "42. Aquel alemán de ojos amenazantes que se presentó ante Conchita por vez primera fue, paulatinamente, transformándose en una persona afable que problematizaba la representación del ocupante como enemigo.

A través de su diario, Conchita evidencia tener una conciencia política muy desarrollada, aunque sin vinculación particular a un partido $\mathrm{u}$ otro ${ }^{43}$. Comprendía perfectamente lo que había llevado a su familia al exilio, las causas de unos y otros, y las esperanzas que los republicanos españoles tenían depositadas en el conflicto internacional. Esta conciencia, lejos de diluirse durante los años de Ocupación, se acrecentó y ello reforzó su identidad como refugiada española. Así, fue definiendo su

\footnotetext{
${ }^{39}$ Ibid., p. 69.

${ }^{40}$ Ibid., p. 70. La cursiva es nuestra.

${ }^{41}$ Robert Gildea, Marianne in Chains...op. cit., pp. 70 y 87.

${ }^{42}$ Conchita Ramírez, Diario de una niña exiliada...op. cit., p. 71. La cursiva es nuestra.

${ }^{43}$ Años después, tras casarse con un militante del PCF, simpatizó con la causa comunista, aunque nunca llegó a militar.
} 
posición y el lado en el que le tocaba situarse en el marco de aquel enfrentamiento y, aunque tuvo mucho cuidado, no lo escondió en sus conversaciones con los ocupantes: "Discuto muy a menudo de política con los alemanes y uno de estos días me van a enviar a trabajar en las fábricas de armamento de Alemania como castigo. Ya lo han hecho con otras personas" 44 .

Lo interesante en este sentido es observar cómo su conciencia política convivió con la amabilidad y el respeto que, a menudo, los ocupantes demostraron hacia ella. Así, si bien su cotidianidad bajo la Ocupación no hizo tambalear sus convicciones políticas, al ponerse en entredicho la imagen del "enemigo", se vio obligada a justificar continuamente su buena relación y, especialmente, a eximirles de responsabilidades. Al entender de Conchita, aquellos soldados, doctores, enfermeras y suboficiales eran alemanes, no nazis. Y es que aunque la relación formal entre ellos fuera de "ocupanteocupado", "vencedores-vencidos", los sufrimientos respectivos de la guerra, la pérdida de seres queridos y las preocupaciones que compartieron hicieron de la empatía un vector de comunicación y entendimiento; ambos eran víctimas de aquel conflicto, no “enemigos". Ello alteró sustancialmente la relación de poder existente entre las dos partes $^{45}$.

Un lunes 11 de mayo de 1942, Conchita recogió en su diario la despedida de uno de los suboficiales de su servicio: “(...) se marcha a París, es alemán, pero para nosotros ha sido muy bueno y hasta le hemos hecho un obsequio (...). A mi me llama "meine kleine" Conchita, quiere decir mi pequeña". A lo que seguidamente, añadió: "claro que todos los alemanes no son malos, ya que los primeros que han sufrido del nazismo son ellos mismos" 46 . En esta misma línea, un mes después, anotaba: "Hoy un enfermo me confesaba que estaba muy inquieto porque no recibía noticias de su familia, que vive en Cologne, ciudad de Alemania que ha sufrido un terrible bombardeo. Yo pensé ¿quién sabe si este aviador no es uno de aquellos que bombardearon tan salvajemente mi España? Ahora lo están pagando. Sin embargo, le animé y le di esperanzas" ${ }^{47}$. Más adelante, en septiembre del 43, tras conocer a Hans, un soldado prusiano, escribió: "le

\footnotetext{
${ }^{44}$ Conchita Ramírez, Diario de una niña exiliada...op. cit., p. 85. Véase también pp. 68 y 70.

${ }^{45}$ Robert Gildea, Marianne in Chains...op. cit., p. 71.

${ }^{46}$ Conchita Ramírez, Diario de una niña exiliada...op. cit., p. 78.

${ }^{47}$ Ibid., p. 80.
} 
digo que [los prusianos] son los peores, pero no se enfada y me dice que si los conociera bien no diría eso. Es verdad -continuaba- no hay que generalizar, son los Gobiernos los responsables del comportamiento de la gente" ${ }^{\text {48 }}$. El diario fue para Conchita un dispositivo realmente útil para dialogar con las contradicciones que día a día vivía ${ }^{49}$. Entre discursos y experiencias, esta joven refugiada intentó entender quiénes eran aquellos ocupantes y, a su vez, los "poderosos" culpables de aquella injusta realidad que a unos y a otros les tocaba vivir ${ }^{50}$.

Como avanzábamos, la sexualidad fue uno de los elementos constitutivos de la relación de poder que entabló con los alemanes en el ámbito laboral. Sabemos que los contactos sexuales entre los soldados alemanes y las mujeres francesas no fueron aislados $^{51}$. Un 29 de septiembre de 1942 Conchita recogía en su diario que no tenía muy buena relación con Lise, su compañera de trabajo, porque si bien en un "principio la estimaba y compadecía por tener a su marido prisionero en Alemania, (...) luego me enteré que tenía un amante, que era el enfermero alemán de nuestro servicio y creía que esto le daba derecho a imponernos su voluntad" ${ }^{32}$. Esta suerte de indignación que parece mostrar nuestra protagonista fue, según Julian Jackson, relativamente frecuente en los diarios de la época, que representaban estas relaciones como "momentos reveladores de la humillación de la Ocupación" 53 . Sin embargo, la posición de poder que la Ocupación otorgó a los alemanes con respecto a las francesas y, en este caso, a Conchita, no impidió -en general- que las relaciones entre hombres y mujeres guardaran los códigos del cortejo y el amor ${ }^{54}$ :

\footnotetext{
${ }^{48}$ Conchita Ramírez, Diario de una niña exiliada...op. cit., p. 98.

${ }^{49}$ Guadalupe Adámez, entre otros, ha insistido en la importancia que la escritura tiene en contextos de crisis y, en particular, lo necesaria que fue para los exiliados republicanos, casi como una especie de terapia y refugio emocional (Guadalupe Adámez, "La escritura necesaria: el uso de la correspondencia en las Memorias y Autobiografías de los exiliados españoles", en Alejandra Ibarra (coord.), No es país para jóvenes, (Instituto Valentín Foronda, 2012).

${ }^{50}$ Penny Summerfield ha puesto de relieve lo útiles que son los diarios para los historiadores interesados en capturar las contradicciones e incoherencias del día a día (Penny Summerfield, Histories of the Self...op. cit., pp. 61-62)

${ }^{51}$ Julian Jackson, France. The Dark Years... op. cit., p. 355; Anne Sebba, Les parisiennes... p. 30 (del prólogo)

${ }^{52}$ Conchita Ramírez, Diario de una niña exiliada...op. cit., p. 87.

${ }^{53}$ Julian Jackson, France. The Dark Years... op. cit., p. 336.

${ }^{54}$ Robert Gildea, Marianne in Chains...op. cit., p. 79.
} 


\section{Marzo de 1942. Miércoles 4}

(...) He recibido otra declaración de amor, hoy de un suboficial llamado Heinz Budde. Este quiere casarse conmigo, le dije que está loco ${ }^{55}$.

Septiembre 1943, Sábado 11

(...) Hay un joven enfermo muy enamorado de mí, tanto que todos los enfermos de la sala lo saben y se burlan de él. (...) Se llama Hans y es prusiano ${ }^{56}$.

Febrero de 1944

(...) Ya he recibido carta de Hans, siempre tan enamorado, me dice que (...) como lectura se ha comprado "Don Quijote", para acercarse más a mí y comprender el carácter español ${ }^{57}$.

De la misma manera, la posición subordinada de las francesas y de Conchita entre ellas, no las despojó de su agencia, su capacidad para protestar y negarse a proposiciones y acciones consideradas inadecuadas e irrespetuosas. Las reglas también fueron negociadas entre ellos ${ }^{58}$ :

(...) estaba yo limpiando el espejo de la sala, se me acercó por detrás e hizo ademán de tocarme el pecho, me volví furiosa y le di una bofetada bien sonora (...). ¡La que se armó! (...) Entonces el doctor ordenó que lo ataran a la cama, (...) pero no duró mucho tiempo. Se presentó en la cocina, se puso de rodillas y me pidió perdón, me dijo que los otros lo provocaban para que demostrara que era un hombre. Por fin le perdoné, pues daba pena verlo, era muy desgraciado y se veía que era sincero ${ }^{59}$.

Richard Vinen ha puesto de relieve que los franceses a menudo debatían sus formas de comportarse con los alemanes, "pusieron mucho énfasis en el silencio (...) y en la necesidad de evitar el cruce de miradas con ellos. Incluso los colaboradores -

\footnotetext{
${ }^{55}$ Conchita Ramírez, Diario de una niña exiliada...op. cit., p. 76.

${ }^{56}$ Ibid., p. 98.

${ }^{57}$ Ibid., p. 102.

${ }^{58}$ Robert Gildea, Marianne in Chains...op. cit., pp. 87-88.

${ }^{59}$ Conchita Ramírez, Diario de una niña exiliada ...op. cit., p. 101
} 
añadía- pensaron que debían poner límites a la intimidad entre vencedores y vencidos" ${ }^{\prime 60}$. Así, Conchita, como las francesas, era plenamente consciente de hasta dónde podía llegar su trato con los alemanes. Aunque su relación fuera cordial con ellos, no dejaban de ser, de una u otra forma y a ojos de su familia y sus seres queridos, el "enemigo", y ello implicaba una serie de restricciones y pautas que debían ser respetadas. En este contexto no es de extrañar que su descripción de un joven alemán que le había declarado su amor finalizara de la siguiente manera: "Me ha confesado que está enamorado de mí, no me desagrada, es muy guapo, moreno con unos verdes muy hermosos. ¿Qué lástima que sea alemán!" 61 . Estas ambivalencias cotidianas no fueron, en absoluto, excepcionales. El diario de la parisina de 14 años, Micheline Bood, recogió emociones muy similares que no ilustran sino la ineficacia de las dicotomías desde las que, durante mucho tiempo, han intentado comprenderse estos complejos años: "Detesto y siempre detestaré a los Boches $^{62} \ldots$ pero los alemanes, tomados individualmente, son normalmente agradables y correctos...Ya no pienso que esté mal hablar con un alemán”. Tiempo después, al descubrir que su amiga Monique se había enamorado de un alemán que, además, la había besado, manifestaba: “Una puede enamorarse de un boche, pero él seguirá siendo un boche" ${ }^{\text {63 }}$.

En junio de 1943 Conchita anotaba en su diario: "El parte de guerra ya no es tan favorable para los alemanes y están rabiosos" ${ }^{\text {64 }}$. Aunque lo venía haciendo desde que empezó la contienda, a partir de entonces siguió muy de cerca el transcurso de la misma que, poco a poco, llegaba a su final. Uno de los últimos episodios que vivió con ellos en el hospital ocupó unas cuantas páginas de su diario y la situaron de nuevo en una posición complicada en el marco de relaciones ocupante-ocupado, especialmente en aquel contexto de inminente liberación:

\footnotetext{
${ }^{60}$ Richard Vinen, The Unfree French...op. cit., p. 113.

${ }^{61}$ Conchita Ramírez, Diario de una niña exiliada...op. cit., p. 74. La cursiva es nuestra.

${ }^{62}$ Término despectivo para referirse a los ocupantes.

${ }^{63}$ Extractos citados en Julian Jackson, France. The Dark Years... op. cit., p. 337. Las referencias del diario: Micheline Bood, Les années doubles. Journal d'une lycéenne sous l'Occupation, Robert Lafont, 1974.

${ }^{64}$ Conchita Ramírez, Diario de una niña exiliada...op. cit., p. 93.
} 
Agosto 1944. Sábado 12

(...) A las seis me sentí con fiebre y me dolía el vientre. El enfermo alemán me puso un termómetro y tenía más de $38^{\circ} \mathrm{C}$. (...) El doctor (...) me dijo que era una crisis de apendicitis. Me preguntó si quería ser operada por ellos ya que es urgente intervenir. Yo le dije que sí. (...) Mis compañeras de trabajo cuando se enteraron vinieron a persuadirme para que no me operaran los alemanes, no tenían confianza en ellos. Yo sí, les dije. (...)

\section{Viernes 18}

El doctor Dunpert entró en la habitación para comunicarme que debía salir del Hospital ese mimo día. Me dijo que todos los enfermos y el personal sanitario alemán habian empezado por la mañana a evacuar. Así pues me quitó los puntos, se despidió deseándome pronta recuperación y dio órdenes para que llamaran a una ambulancia francesa ${ }^{65}$.

En definitiva, en la experiencia de Conchita, como en la de muchas francesas, fue el espacio laboral el que albergó las relaciones más estrechas con los alemanes y, sin embargo, al menos en nuestro caso, las más flexibles. Relaciones de poder negociadas y con reglas, en general, respetadas, que estuvieron lejos de ser entendidas en términos de opresión-resistencia. La escala de grises, en cuanto a comportamientos, actitudes, prácticas y concepciones, se mantuvo siempre dentro de las estructuras del poder ${ }^{66}, \mathrm{y}$ ello no solo agudizó su ingenio, su agencia y capacidad de acción, sino que le permitió sobrevivir emocional y materialmente en este primer espacio de cohabitación.

\footnotetext{
${ }^{65}$ Ibid., pp. 107-109.

${ }^{66}$ Seguimos a Judith Butler y su "paradoja de la sujeción" al entender que no es posible escapar de las estructuras del poder, sino que paradójicamente, las relaciones de poder que te dominan y te subordinan a una lógica institucional, social o cultural, son las que te convierten en sujeto, te hacen existir, te permiten elaborar una idea de ti a partir de la que enunciarte y, así, resistir, negociar, actuar. (Judith Butler, Cuerpos que importan. Sobre los límites materiales y discursivos del sexo, México D. F.: Paidós, 2002, p. 38. Asimismo, véase: Judith Butler, Mecanismos psíquicos del poder. Teorías sobre sujeción. Madrid: Cátedra, 2001. Anne Montenach, "Agency: ¿un concept opératoire dans les études de genre? Introduction", Rives méditerranéennes, 41, (2012), p. 8). Desde la Alltagsgeschichte, las reflexiones en este sentido son asimismo muy útiles (Especialmente: Paul Steege $e t$ at, "The History of Everyday Life: A Second Chapter", The Journal of Modern History, vol. 80, n. 2, (2008), pp. 358-378)
} 


\section{HOGAR Y COMUNIDAD}

Diciembre de 1941. Lunes 29.

Hoy cumplo dieciocho años. A pesar de mi juventud no me siento muy feliz, cada año que pasa es más dramático. ¿Cuánto tiempo va a durar esta guerra y esta terrible ocupación? Vivimos con la esperanza de volver pronto a España, esto nos ayuda a soportar tantas miserias ${ }^{67}$.

La cotidianidad de Conchita se mostró aún más ambivalente ante la situación que se vivió en su hogar y que padecieron familias amigas y cercanas a ellos, como los Torralba. Desde el prisma de su hogar y la comunidad que conformaron las dos familias, la imagen de la Ocupación y del ocupante se transformó radicalmente. Una imagen mucho más cruda, más triste y humillante, de relaciones de dominación más firmes que contrastó y, paradójicamente, convivió con la del respeto y las declaraciones de amor que, a grandes rasgos, proyectaba el espacio laboral.

El hogar de Conchita lo conformaban sus cuatro hermanos menores, su madre y su padre. La hermana mayor de la familia se había quedado en España junto a su tía y su abuela, y ello los obligó a gestionar emocionalmente un hogar que era, a todas luces, transnacional ("Hemos recibido carta de Julia, nos dice que está bien así como abuelita y tita Teresa" ${ }^{98}$ ). Sus hermanos pequeños iban a la escuela y su madre trabajaba en el hogar, como una de tantas madres de familia que, durante los duros "años negros", actuaron como "administradoras de lo cotidiano y guardianas del hogar"69. Gestionaron, con ingenio, la poca comida que entraba en casa ${ }^{70} \mathrm{y}$, de igual manera, se esforzaron por vestir a sus hijos dignamente. El empeño, la capacidad y la habilidad desarrollada por estas mujeres en cotidianidades tan extremas como la de la Ocupación, fue una auténtica garantía de supervivencia:

\footnotetext{
${ }^{67}$ Conchita Ramírez, Diario de una niña exiliada...op. cit., p. 73.

${ }^{68}$ Ibid., p. 72.

${ }^{69}$ Dominique Veillon, "La vie quotidienne des femmes sous l'occupation"...op. cit., p. 41. Célia Bertin: Femmes sous l'Occupation, (Paris: Stock, 1993), especialmente el capítulo 2.

${ }^{70}$ En este sentido, véase: Paula Schwartz, “The politics of food and gender in occupied Paris"...op. cit.
} 


\section{Mayo de 1942. Viernes 1.}

Mamá me ha hecho un traje sastre rosa precioso. ¡Cuánto economizamos con las manos de mamá! Y además estamos vestidos con gran gusto y elegancia, a pesar de nuestros escasos medios ${ }^{71}$.

Como indicábamos con anterioridad, eran su padre y ella los encargados de trabajar fuera de casa, con el único fin de contribuir a la economía familiar ${ }^{72}$. Ella sabía que tanto su aportación como la de su padre eran indispensables, y no solo en términos de salario, sino también en cuanto a la comida que ambos podían sustraer de sus respectivos espacios laborales: "Tan solo papá y yo trabajamos (...) y la comida que podemos llevar a casa es primordial con la escasez que hay. Únicamente los que tienen mucho dinero pueden comprar en el mercado negro"73. Las consecuencias de estos "hurtos morales"74, para ellos plenamente justificados, pudieron ser sorteadas por Conchita, pero no así por su padre, que llegó a ser detenido y encarcelado. “¿Su delito? -escribía un viernes 17 de julio de 1942- haberle encontrado varios kilos de patatas a la salida del trabajo. ¡Qué ignominia!" ${ }^{75}$. Este episodio la condujo a interactuar de nuevo con los ocupantes, pero en un contexto, unos términos y una posición totalmente distinta a la que estaba acostumbrada. "A las nueve fui a la Feldkomandatur, me recibió el mismo suboficial, tan antipático (...). De rabia me fui sin decir nada, pero maldiciéndolos. Se burlan porque son los más fuertes" ${ }^{\text {76 }}$. Días después fue con su madre a llevar un paquete a su padre, y expresó un sentimiento de subordinación similar: "Hubo un altercado entre una joven muy elegante y un soldado alemán (...). La joven se marchó llorando, impotente ella y nosotros, por no poderla ayudar. Eran los más fuertes, hasta ese simple soldado, que sin duda, no tenía ni el certificado de estudios"77. Su

\footnotetext{
${ }^{71}$ Conchita Ramírez, Diario de una niña exiliada...op. cit., p. 78.

72 "He ganado lavando, 250 francos. Este dinero se lo doy a mi madre para que compre la ropa y zapatos que necesitamos y mi salario íntegro, se lo entrego a mi padre, hasta el último céntimo". (Conchita Ramírez, Diario de una niña exiliada...op. cit., p. 77). El padre trabajaba en la Intendencia con los alemanes, según Conchita, "cargando sacos de mucho peso a los hombros" (p. 66)

${ }^{73}$ Conchita Ramírez, Diario de una niña exiliada...op. cit., p. 86.

${ }^{74}$ Óscar Rodríguez Barreira, Migas con miedo. Prácticas de resistencia al primer franquismo. Almería, 1939-1953, (Almería: Universidad de Almería, 2008), p. 200.

${ }^{75}$ Conchita Ramírez, Diario de una niña exiliada...op. cit., p. 82.

${ }^{76}$ Ibid., p. 83.

${ }^{77}$ Ibid.
} 
desprecio hacia el ocupante y su indignación hacia las injusticias y los abusos que ellos protagonizaron, vuelven en su diario a identificar y personificar al "enemigo". Desde el hogar y la comunidad, la experiencia de la Ocupación era mucho más ardua y penosa. Esta cara más cruda le recordaba, además, su situación de refugiada española, su subalternidad, su vulnerabilidad y su indefensión en un país del que no eran ciudadanos y en el que no tenían más redes de protección y apoyo que las de su hogar y las tejidas con la familia vecina. Por esta razón, "vivir con la esperanza de volver pronto a España”, elemento central de la identidad de refugiado ${ }^{78}$, les ayudó a sobrellevar las penurias de aquel régimen y, a su vez, a no perder de vista sus orígenes y las razones de su estancia en Francia.

La familia Torralba, antiguos inmigrantes españoles, se componía de seis miembros: los padres y cuatro hijos varones. Uno de ellos, Gaby, había luchado en la guerra civil, al término de la cual fue internado en Septfonds (Tarn-et-Garonne), donde se ubicó uno de los campos de refugiados españoles ${ }^{79}$. La sintonía ideológica y humana estuvo presente desde el primer momento en que se conocieron, por lo que ambas familias mantuvieron una relación muy estrecha, de amistad y ayuda mutua durante todos estos años. Relación que se vería reforzada en 1946 tras el matrimonio de Conchita con Gaby. A los pocos meses de la Débâcle, en noviembre de 1940, detuvieron al padre de familia y a los cuatro hijos, y los internaron en el campo de concentración de Merignac (Gironde) ${ }^{80}$. Desde ese momento, la madre de la familia se convirtió en la viva imagen de la supervivencia, la extenuación y el dolor en tiempos de guerra y terror de un régimen altamente represivo:

\section{Julio de 1941. Domingo 13.}

Pienso mucho en Gaby. No puedo olvidarlo. He sabido que al padre lo han metido en el barracón de los primeros a fusilar. Su pobre mujer trabaja en una colonia de niños de cocinera, y luego se va a pie hasta el campo de Merignac, que está a bastantes kilómetros de

\footnotetext{
78 Jorge de Hoyos, "La formación de la identidad del refugiado: los republicanos españoles en México, discursos, prácticas y horizontes de futuro", Laberintos, n.14, (2012), pp. 49-68.

79 Sobre el campo de Septfonds se ha publicado recientemente el libro de Geneviève Dreyfus-Armand, Septfonds 1939-1944. Dans l'archipel des camps français, Perpignan, Le Revenant éditeur, 2019.

${ }^{80}$ A partir de noviembre de 1940 las Autoridades de Ocupación internaron en este campo a sospechosos políticos y más adelante a judíos. Véase: Florent Leruste, Juifs interés à Bordeaux (1940-1944): Le camp de Mérignac-Beaudésert, (Les Éditions du Net, 2014).
} 
Chambery, va cargada con comida, ropa y otras cosas que necesitan los prisioneros. No parece la misma, ha adelgazado mucho y ya no es tan coqueta como antes ${ }^{81}$.

En junio de 1943 Conchita supo que Gaby había sido internado en un campo de concentración en Polonia, y en abril de 1944, anotó: "He visto a su madre, está muy delgada y envejecida (...) me dijo que el campo donde está Gaby es de los más terribles, se llama Auschwitz, se encuentra en Silesia, Polonia" ${ }^{\sharp 2}$. Puesto que en el hospital Conchita estaba aprendiendo alemán, se ofreció a traducir las pocas letras que, censuradas, le llegaban a la madre. Esta ayuda constituyó su forma de hacer frente a las injusticias que no podía denunciar en el espacio público. En su diario no desveló el contenido de las mismas, pero la experiencia de los Torralba y las informaciones difusas que llegaban situaron en su cotidianidad la dimensión más traumática de la guerra y la ocupación: las deportaciones, el trabajo forzado y los "espacios de excepción" 83 que representaron aquellos campos en los que fueron internados.

En aquellos momentos se desconocía la dimensión de todo aquel horror, pero los índices de violencia, control y coerción que ya se advertían y que padecieron más directamente su padre y la familia vecina, consiguieron en cierto modo coaccionarla. ¿Supone esto pensarla como una mera espectadora de la dominación? A nuestro entender, Conchita encontró en los miembros de su comunidad y en su diario la vía de escape a todo lo que no podía expresar en su relación con las instituciones de ocupación. Era consciente de su posición de subalternidad y, por tanto, sabía en qué momentos y en qué espacios era o no posible enfrentarse a ellos. Y es que "vivir con el enemigo" implicaba relaciones de poder múltiples, a veces más flexibles y otras veces menos, pero siempre mediadas por el tiempo, el espacio y la posición de ambas partes. No pensamos, por tanto, que fuera una mera espectadora de la dominación, sino una superviviente que lidió con la complejidad de su vida cotidiana bajo la Ocupación y manejó, como pudo,

\footnotetext{
${ }^{81}$ Conchita Ramírez, Diario de una niña exiliada ...op. cit., pp. 71-72.

${ }^{82}$ Ibid., pp. 96 y 103.

${ }^{83}$ El concepto lo tomamos de Giorgio Agamben: "El campo de concentración es el espacio que se abre cuando el estado de excepción empieza a convertirse en regla. Así, el estado de excepción, que era esencialmente una suspensión temporal del ordenamiento sobre la base de una situación real de peligro, adquiere ahora un sustrato especial permanente que, como tal, se mantiene, sin embargo, de forma constante fuera del orden jurídico" Giorgio AGAMBEN, Homo Sacer. El poder soberano y la vida nuda, (Madrid: Pre-textos, 2006, p. 215)
} 
su agencia y capacidad de acción en los diferentes escenarios que conformaron el teatro de aquel régimen.

\section{LA CALLE, EL CINE, EL TRANVÍA}

Los espacios de indeterminación y de ocio también articularon la vida cotidiana de Conchita bajo la Ocupación. Las calles de Burdeos por las que transitó a diario, los cines que frecuentó y las películas que visionó, así como el tranvía que cada día la llevó de su casa al hospital en el que trabajaba recogieron imágenes, episodios y relaciones que, de igual manera, nos hablan del régimen de Ocupación más allá de las instituciones $\mathrm{y}$, especialmente, de las diferentes formas en que los habitantes como ella, pudieron entenderlo, percibirlo y padecerlo. La ciudad de Burdeos tenía cerca de 260.000 habitantes, lo que la convertía en la segunda ciudad más grande -después de París- de la zona ocupada. Era también un lugar estratégico por su puerto con acceso al Atlántico y al imperio colonial, por lo que su control por los alemanes era crucial ${ }^{84}$. Pero la ciudad, más allá de constituir una posición valiosa desde el punto de vista militar, era también un escenario de posibilidades y peligros para el ocupante y para el ocupado. Un lugar idóneo para transmitir ideas, mensajes y advertencias a través de espacios resignificados, de propaganda, simbología y presencias, así como un lugar con oportunidades para evadirse de ellas a través del ocio, nuevos aprendizajes, la movilidad o el anonimato ${ }^{85}$. ¿Cómo vivió Conchita la ciudad ocupada?

Al inicio de la ocupación, el desorden y la confusión se apoderó de la ciudad de Burdeos, que vio triplicar su población con la llegada de refugiados del norte Francia y Bélgica $^{86}$. Sin embargo, con el pasar de los días, la vida se fue normalizando y habituándose a aquella nueva realidad. La aparente continuidad que reinaba en sus calles y en sus viandantes generó malestar a Conchita en no pocas ocasiones. E1

\footnotetext{
${ }^{84}$ Françoise Taliano-Des Garets, "Bordeaux sous 1'Occupation: collaboration, attentisme et résistance", Association pour la connaissance de l'Allemagne d'aujourd'hui, n²25, (2018), pp. 166-172, p. 167.

${ }^{85}$ Sobre la ciudad como espacio de posibilidades y de conflicto: Leif Jerram, Streetlife: the Untold History of Europe's Twentieht Century, (Oxford: Oxford University Press), 2011. Judith R. Walkowitz, La ciudad de las pasiones terribles, (Madrid: Cátedra, 1992). Ruben Pallol, "La lucha por la calle. Conflictos en la redefinición del espacio público en las ciudades de comienzos del siglo XX", Crisol, 5, (2019), pp. 1-34. Sobre la ciudad ocupada: Alejandro Pérez-Olivares, "Vigilar y controlar. Espacio público, espacio privado y violencia en el Madrid ocupado (1938-1940)", en Gloria Román y Juan Antonio Santana (coords), Tiempo de dictadura. Experiencias cotidianas durante la guerra, el franquismo y la democracia, (Granada: Editorial Universidad de Granada, 2018), pp. 67-89.
}

${ }^{86}$ Françoise Taliano-Des Garets, “Bordeaux sous l'Occupation... op. cit., p. 167. 
contraste que encontraba al salir del hospital, donde el sufrimiento físico y psíquico de la guerra imperaba sobre todas las cosas, la llevó a entender la calle como un lugar perversamente ajeno al horror del contexto que se vivía: "Octubre de 1942. Domingo 4. Cuando salgo del Hospital, donde asisto a tantos sufrimientos y me encuentro en la calle, con la gente paseándose tan tranquila, me produce horror un mundo tan feo y todo por culpa de unos cuantos" 87 .

Las calles de la ciudad también resultaron incómodas para Conchita por otras razones. El espacio público estaba sujeto a unas normas no escritas que restringieron la libertad de sus habitantes, sobre todo en lo que respecta a las relaciones con el ocupante. Las conductas y actitudes fueron especialmente controladas por unos y otros, por ello, acciones como las de hablar o pasear con los alemanes debían ser evitadas ${ }^{88}$. En este sentido, la calle también generó un incómodo contraste para nuestra protagonista, quien estaba acostumbrada a relacionarse con ellos en su espacio laboral:

Marzo de 1942. Jueves 26.

Al salir del trabajo me encontré en la parada del tranvía con Helmut. Esto me contrarió, en la calle no quiero hablar con alemanes. Me dijo que quería verme, que le diera una cita, en aquel momento apareció Otto, el cocinero, que me sigue por todas partes. Afortunadamente llegó el tranvía y los dejé plantados a los dos ${ }^{89}$.

A pesar de la voluntad por evitarlos en público, por no cruzar miradas ni hablar con ellos, la presencia de los ocupantes se materializaba diariamente a través de los desfiles, de la simbología que adornaba los espacios ocupados, de las señales de tráfico, de la hora alemana, de la música y los conciertos, así como de la propaganda ${ }^{90}$. Esta omnipresencia era también llamadas al orden y al recuerdo de que habían sido vencidos. Conchita recogió en su diario algunas de estas imágenes que las calles ofrecían: "Fui

\footnotetext{
${ }^{87}$ Conchita Ramírez, Diario de una niña exiliada...op. cit., p. 87.

${ }^{88}$ Richard Vinen, The Unfree French ...op. cit., p. 113.

${ }^{89}$ Conchita Ramírez, Diario de una niña exiliada...op. cit., p. 87. La joven parisina, Micheline Bood, expresa situaciones muy similares en su diario: "Él me acompaño hasta el metro y me sentí avergonzada por la forma en la que me miraba la gente". Ello la obligó a advertirle de que fuera de la propiedad no podía pasear juntos. (Julian Jackson, France. The Dark Years... op. cit., p. 337)

${ }^{90}$ Françoise Taliano-Des Garets, "Bordeaux sous l'Occupation... op. cit., p. 167. Esto es lo que Michael Billig ha denominado como "nacionalismo banal" (Michael Billig: "El nacionalismo banal y la reproducción de la identidad nacional", Revista mexicana de sociología, 60-1, (1998), pp. 37-57)
} 
con Lucienne a Burdeos. Vimos en la Place de la Victoire un inmenso mapa, instalado por los alemanes, de toda Europa y mostrando el avance de sus tropas en el frente ruso" $"$.

\section{Imagen no 1. Panel de propaganda "La Europa Victoriosa", ubicado en la Place de la Victoire, Burdeos, 1941}

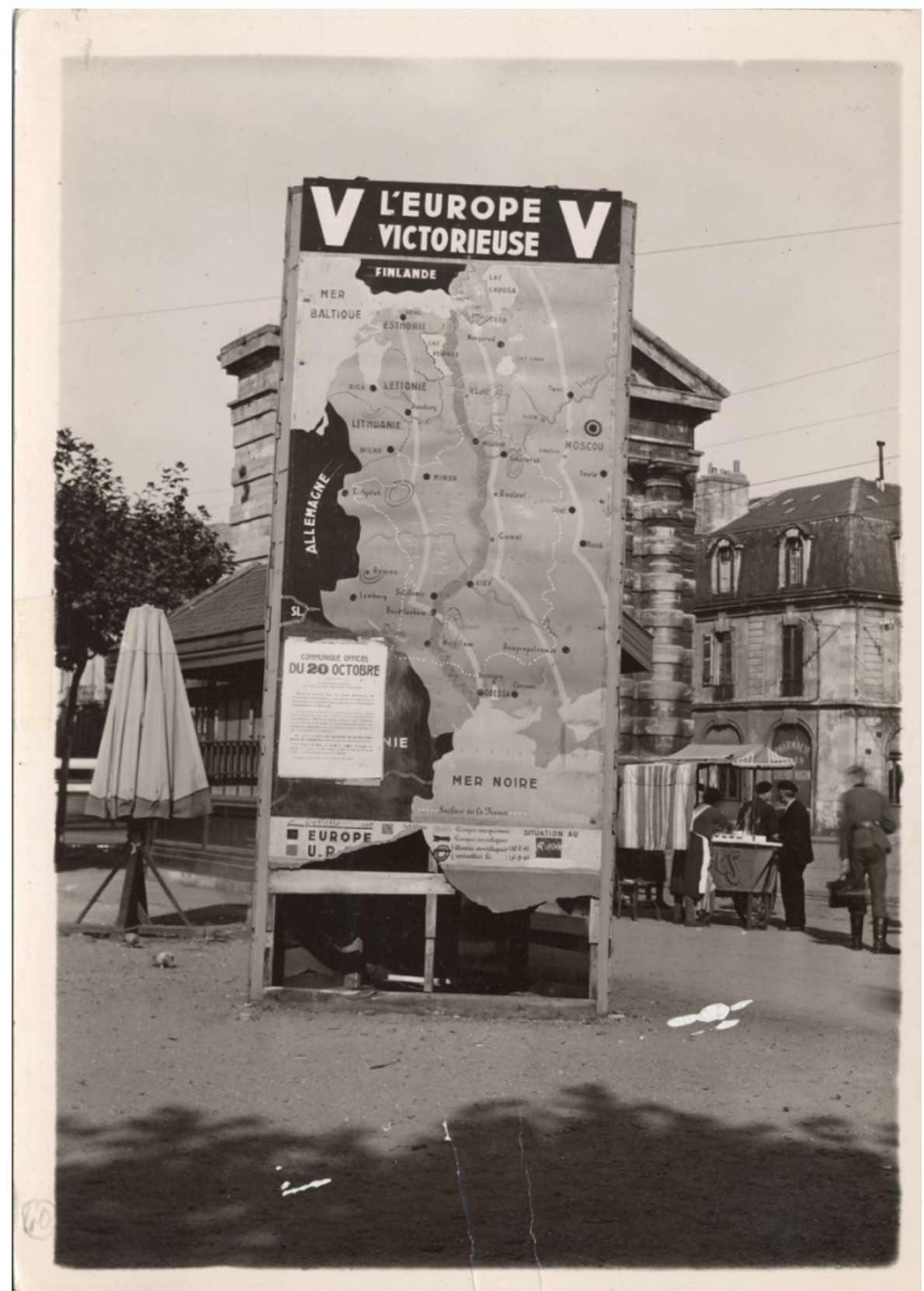

Fuente: Archives Bordeaux Métropole (ABM). 21Fi95

${ }^{91}$ Conchita Ramírez, Diario de una niña exiliada...op. cit., p. 74. 
Otras imágenes que impactaron a Conchita y, de una manera mucho más violenta, le recordaron la presencia cotidiana de los ocupantes, fueron las relacionadas con la política antisemita y todo el aparato represivo y de exterminio nazi:

\section{Junio de 1942. Sábado 6.}

Por primera vez he visto pasar a dos judias, se reconocen porque los alemanes las obligan a llevar cosida en sus ropas una gran estrella amarilla de seis puntas, y vi como un hombre las insultaba. También a los niños les imponen esa estrella, que esconden debajo de los libros y se ven muy tristes. ${ }^{92}$

Abril de 1944. Miércoles 5.

Cuando salimos, vimos a un hombre gritando, en medio de la calle y decía que los alemanes torturaban y mataban en los campos de concentración. Nos quedamos escuchando y de pronto, no se sabe de dónde, salió una patrulla, dispersó a la gente. Yo creo que se lo llevaron. Pobre hombre, iqué le harán! ${ }^{93}$

Pero la ciudad también albergó espacios de encuentro desde los que evadirse, resistir y divertirse. Desde Chambery hasta Burdeos, Conchita se desplazaba todos los días en tranvía. Éste le garantizaba la movilidad y, con ella, salir del ámbito doméstico y comunitario, "escapar" del control familiar y conocer a personas nuevas con las que hablar, aprender y repensar las relaciones de género imperantes. El propio tranvía, más allá de comunicar el punto de salida y de llegada, se convirtió para ella en uno de estos lugares. "He conocido a un joven en el tranvía" - escribía un jueves 1 de diciembre de 1941-. Se llamaba André Fousquet y era técnico de electricidad en Correos. "Es muy instruido -añadía- lee mucho y gracias a él he podido leer la buena literatura francesa. Me ha prestado muy buenos libros que yo no hubiera podido comprarme y me ayuda a perfeccionar este idioma. El tranvía es mi escuela" ${ }^{94}$. Coincidió con él a diario y entablaron una estrecha relación que se mantuvo durante los años de la Ocupación, pero muy al pesar del joven, Conchita no llegó a sentir nada más allá de la amistad: "Pienso si no hago una tontería en no decidirme, pero no le quiero y aunque tiene una buena situación y para mi terminaría la pobreza, medito y me pregunto ¿se puede vivir al lado

\footnotetext{
${ }^{92}$ Ibid., p. 80.

${ }^{93}$ Ibid., p. 103.

${ }^{94}$ Ibid., pp. 73-74.
} 
de un hombre toda una vida sin sentir ninguna atracción por él?" ${ }^{95}$. Además de estos constructivos encuentros, el tranvía también acogió episodios que impresionaron a la joven refugiada, que no solo le recordaban la vigencia del régimen de ocupación y se convertían en advertencias cotidianas, sino que además denotaban que la ciudad, sus espacios y dinámicas no podían ser del todo controladas por los ocupantes:

\section{Abril de 1942. Lunes 13.}

En el tranvía ocurrió un suceso, pues cuando se llega al Boulevard, la cobradora cierra las puertas de un lado y abre las otras, al cambiar de sentido, es decir al salir de la ciudad, en ese momento vimos saltar del tranvía a un joven que echó a correr desesperadamente, perseguido por dos alemanes que también estaban en el tranvía, y pensábamos que lo llevaban prisionero. El joven aprovechó el cambio de puerta, cosa que los alemanes no sabían ${ }^{96}$.

La ciudad de Burdeos, como otras muchas, fue una ciudad en conflicto. En sus calles, como en sus medios de transporte o sus espacios ocupados convivieron escenas e imágenes contradictorias, opuestas e inquietantes que no pasaron desapercibidas para nuestra joven refugiada española. Junto a ellas, la ciudad siguió ofreciendo espacios dedicados al ocio, a la cultura y al espectáculo, como fueron los cines y los teatros. Algunos como el Théâtre Français y el Cine Rex fueron ocupados y transformados en Soldatenkinos $^{97}$, pero otros situados más a las afueras como el ubicado en Nansouty, fueron frecuentados muy habitualmente por Conchita, su familia y sus amigos.

\footnotetext{
${ }^{95}$ Ibid., p. 79.

${ }^{96}$ Ibid., p. 77.

${ }^{97}$ Cines exclusivos para los soldados alemanes. Françoise Taliano-Des Garets, "Bordeaux sous l'Occupation... op. cit., p. 167.
} 


\section{Imagen 2. EI Teatro Francés de Burdeos convertido en Soldatenkino (1940-1941)}

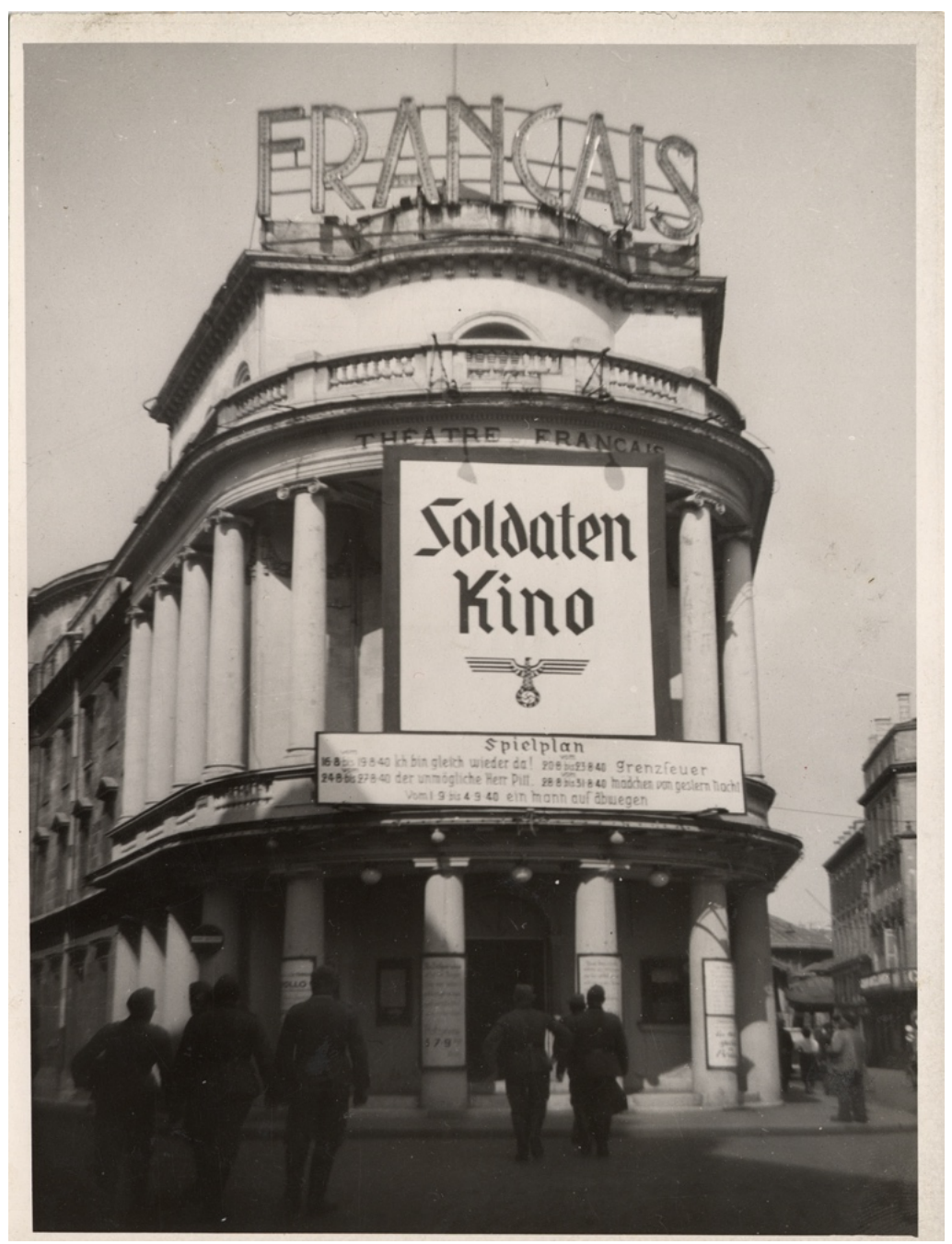

Fuente: ABM. 21Fi71

Paradójicamente, durante los años de la Ocupación, con una Francia derrotada, humillada, controlada, reprimida y hambrienta, la industria cinematográfica francesa vivió una auténtica "edad de oro". El control de la producción y las proyecciones por parte de las fuerzas de ocupación no solo garantizó la supervivencia del sector, sino que le dio un nuevo impulso. Se realizaron un total de 220 largometrajes de ficción que fueron proyectados en zona ocupada y "libre" entre junio de 1940 y agosto de 1944. Sin competencia americana e inglesa, cuyas películas estaban prohibidas, y siendo una de las pocas actividades de ocio permitidas -junto al teatro y el deporte-, el cine francés 
gozó de un éxito excepcional y de unos niveles de audiencia inéditos ${ }^{98}$. En efecto, Conchita, acompañada de su hermana normalmente, pero a veces de otros amigos y familiares, fue una espectadora fiel casi todos los domingos que le era posible. Y es que el cine se convirtió en un refugio emocional desde el que gozar de una cierta autonomía, en una práctica social propicia para olvidar, durante unas horas, la triste realidad en la que estaban inmersos ${ }^{99}$.

A diferencia de lo que podríamos pensar, los discursos antisemitas o antisoviéticos entre otros temas difundidos ampliamente por la prensa y la radio, estuvieron ausentes en la producción cinematográfica de estos años ${ }^{100}$. Lo cierto es que la mayoría de los filmes franceses producidos durante la Ocupación fueron aceptados por la Filmprüstelle (Servicio de censura alemán), y es que el exigente proceso de censura de las autoridades de Vichy, encargadas de visionar las películas antes de enviarlas a los alemanes, junto a la propia autocensura de los guionistas y directores, facilitó la tarea del Servicio alemán ${ }^{101}$. ¿Qué tipo de películas se proyectaron en los cines por los que pasó Conchita y qué imágenes, representaciones y discursos difundieron? ¿De qué forma pudieron interpelarla? ¿Cómo fue su recepción?

Conchita fue una de entre tantas mujeres jóvenes que frecuentaron los cines. Con los varones en el frente, en las Compañías de trabajo, deportados o encarcelados, parece muy probable que ellas hubieran ocupado, en mayor medida que ellos, las butacas de aquellas salas. Esto podría explicar que los filmes rodados durante estos años fueran especialmente sensibles al público femenino, y es que en ellos predominó la imagen de la mujer fuerte, autónoma, dueña de su destino y sus pasiones, y capaz, frente a la debilidad de los hombres o la ausencia de los mismos, de garantizar la supervivencia de

\footnotetext{
${ }^{98}$ Delphine Chedaleux, "Des jeunes femmes dans le cinema français sous l'Occupation: contradictions en noir et blanc", Nouveau Monde éditions, n.12, (2009), pp. 163-173. Jean-Pierre Bertin-Maghit, "Le monde du cinema français sous l'Occupation ou 25 ans de questions aux archives", Vingtième Siècle. Revue d'histoire, n. 88, (2005), pp. 109-120. Michaël Sauvé, Le cinema de fiction durant l'Occupation: le rejet de la Révolution Nationale (1940-1945), Mémoire à la Maîtrise en Histoire, Université du Québec à Montreal, 2017.

${ }^{99}$ En este sentido, véase: Francesca Polletta, "Free spaces in collective action", Theory and Society, 28-1, (1999), pp. 1-38.

${ }^{100}$ Según Jean-Pierre Bertin, tan solo 10 películas de las 220 hicieron referencia explícita a la guerra y la Ocupación (Jean-Pierre Bertin-Maghit, "Le monde du cinema français sous l'Occupation...op. cit., p. 110)

${ }^{101}$ Por supuesto, todos los filmes producidos por judíos fueron prohibidos, y sus estudios, equipos o salas de cine incautados. (Michaël Sauvé, Le cinema de fiction durant l'Occupation... op. cit., p. 38)
} 
la comunidad. Se trataba de una representación femenina alejada del modelo de mujermadre, débil y pasiva, siempre bajo la tutela del varón, que fue tan venerado por el régimen de Vichy, pero, sin embargo, mucho más próxima a la realidad de las mujeres en aquellos tiempos de guerra y Ocupación ${ }^{102}$.

Desafortunadamente, Conchita no recogió con detalle en su diario todas las películas que vio, ni todas sus impresiones sobre las mismas. Algunos de los títulos que anotó fueron las francesas Le destin fabuleux de Desirée Clary (Sacha Guitry, 1942), Cartacalha (León Mathot, 1942) y La fille du puisatier (Marcel Pagnol, 1940). Las tres tuvieron como protagonistas a mujeres fuertes. La última de ellas fue a verla un domingo 27 de diciembre de 1942 junto a su hermana: "vimos La fille du puisatier con Fernandel, muy sentimental y moral", escribió ${ }^{103}$. El filme de Pagnol fue la primera película francesa en ser presentada durante la Ocupación y, además, la primera en pasar la línea de demarcación, siendo proyectada en París y Burdeos. Los cines de París la acogieron durante 21 semanas en cabeza de cartel e ingresaron más de 4.5 millones de francos, "signo del apetito popular por el cine francés", señala Michaël Sauvé ${ }^{104}$. La trama la convirtió en una de las pocas que se ambientaron en el contexto de la Segunda Guerra Mundial y la Dêbacle francesa, y a través de ella se situó en primer plano la figura de la madre soltera y los hijos ilegítimos, aunque no sin su posterior rehabilitación e inserción en la sociedad ${ }^{105}$. Temas presentes en el filme como el respeto de las tradiciones o la "vuelta al hogar", muy propagados por el régimen de Vichy, llevaron a considerarla como colaboracionista y pétainiste. Sin embargo, los últimos estudios sobre el cine francés de la época han encontrado varios elementos que invitan a cuestionar ampliamente esta valoración. Uno de ellos está muy relacionado con los modelos de feminidad y masculinidad que la película proyectó: representaciones masculinas frágiles, fisuras del patriarcado y, especialmente, una protagonista "libre” y

\footnotetext{
${ }^{102}$ Michaël Sauvé, Le cinema de fiction durant l'Occupation... op. cit., p. 139. Delphine Chedaleux, "Des jeunes femmes dans le cinema français sous l'Occupation...op. cit., p. 163.

${ }^{103}$ Conchita Ramírez, Diario de una niña exiliada...op. cit., p. 91.

${ }^{104}$ Michaël Sauvé, Le cinema de fiction durant l'Occupation... op. cit., p. 139. Delphine Chedaleux, "Des jeunes femmes dans le cinema français sous l'Occupation...op. cit., p. 54.

105 Jean-Pierre Bertin-Maghit, “Le monde du cinema français sous l'Occupation...op. cit., p. 112.
} 
capaz de tomar sus propias decisiones, aunque sin subvertir demasiado las estructuras del poder dominante ${ }^{106}$.

Resulta complicado aprehender la recepción que estas películas tuvieron entre las jóvenes que las visionaron. La influencia de las producciones culturales en la configuración de las identidades y subjetividades nunca es perfecta, exacta o lineal, sino que varía en función del contexto sociocultural en el que se inscriben sus espectadores $^{107}$. Aunque Conchita no dejó de anotar en su diario todos los domingos que iba al cine, sus explicaciones lacónicas nos dicen muy poco de su recepción. Sin embargo, la imagen que el diario proyecta de ella parece muy cercana a la de las mujeres protagonistas de los filmes de la época. Es muy posible que su experiencia de la guerra civil, el cruce de la frontera, las relaciones de poder que gestionó y la lucha diaria por la supervivencia propia y familiar en aquel contexto de Ocupación, junto a la representación empoderada de aquellas mujeres que, semana tras semana, contemplaba a través de la gran pantalla, contribuyeran a hacer de ella una mujer fuerte, autónoma y superviviente. La calle, el cine y el tranvía la interpelaron de muy distintas formas y, así, entre los grises de las llamadas al orden y las posibilidades que la ciudad ofrecía se desarrolló la experiencia de Conchita bajo el régimen de Ocupación.

\section{¿LIBERARSE DEL ENEMIGO?}

Agosto 1944. Domingo 27

A las doce de la mañana fuimos a la carretera de Toulouse, por donde llegaban los combatientes F.F.I. Llevaban un brazal rojo en la manga y muchas banderas desplegadas. ¡Por fin los alemanes se han ido! ¡La ocupación de Francia ha terminado!

Martes 29

¿Quiénes son esas personas que pelan a las mujeres que han estado con alemanes? No creo que sean los mismos que los han

combatido.

\footnotetext{
${ }^{106}$ Michaël Sauvé, Le cinema de fiction durant l'Occupation... op. cit., p. 139. Delphine Chedaleux, "Des jeunes femmes dans le cinema français sous l'Occupation...op. cit., p. 58.

${ }^{107}$ Geneviève Sellier, “Gender studies et études filmiques”, Cahiers du Genre, n. 38, (2005), pp. 63-85, p. 77.
} 
Aquel agosto de 1944, Conchita Ramírez celebró la Liberación de Burdeos no sin mostrar su estupor ante escenas como la de las tondues que paseaban por las calles para escarnio público. De nuevo, como sucedía con los alemanes que la trataron con respeto, sintió la necesidad de defender a los que habían liberado Francia y buscar las responsabilidades en otros. A su entender, los mismos que habían combatido a los alemanes, no podían hacer aquella atrocidad. Las contradicciones de la Liberación se vieron reflejadas así en su escrito y la "colaboración horizontal" de la que se las acusaba, de una u otra forma, la interpelaron como mujer que había trabajado con ellos y para ellos, y con los que, además, había entablado una relación de cordialidad y respeto.

Más de setenta años después de aquellos episodios, al ser preguntada por las "rapadas", Conchita contestó recordando el episodio que anteriormente señalábamos: “¡Uy, sí! Yo tenía miedo, eh. Yo cuando salía del hospital...una vez había un alemán que le gustaba yo mucho y lo veo que se acerca a mí y digo: jay madre mía, en la calle no, no quiero nada, eh" ${ }^{\prime 108}$. Ella sabía que si la veían por la calle con un alemán corría el riesgo de ser tachada de "colaboracionista", pero posiblemente en ningún momento pensó que los "delitos sexuales" - cuando los había- ${ }^{109}$ pudieran castigarse con más fuerza que otros, y es que a pesar de que existieran reglas, "las que se aplicaron durante la Liberación, cuando la colaboración horizontal fue castigada con el rapado (...) no eran necesariamente las mismas bajo la Ocupación, cuando las mujeres solteras se enfrentaban a los alemanes en los espacios laborales u otras situaciones sociales". Así, siguiendo a Gildea, "lo que se consideraba como un desafío a la integridad de la comunidad bajo la Ocupación -en el caso de Conchita nos referimos a su familia, como refugiados españoles, y la familia vecina, cuyos hijos sufrían la deportación y la

\footnotetext{
${ }^{108}$ Entrevista realizada por Alba Martínez a Conchita Ramírez, 13-06-2016, Dos Hermanas, Sevilla.

${ }^{109}$ De hecho, más de la mitad de las rapadas estudiadas por Fabrice Virgili fueron acusadas por otro tipo de colaboracionismo, mercado negro, etc, y no por "colaboración horizontal". Por tanto, en palabras de Luc Capdevila, "el rapado fue el castigo sexuado de la Colaboración y no el castigo de una colaboración sexual" (Luc Capdevila, "Identités masculines et féminines pendant et après la guerre", en Évelyn MolinRotureau (dir.), 1939-1945: combats de femmes. Françaises et Allemandes, les oubliées de l'histoire, Autrement, Paris, 2001, pp. 199-220. Cita en p.214)
} 
represión nazi-, fue visto como algo mucho más serio por los tribunales de la Liberación" $" 110$.

Imagen 3 (izq). Salon de Coiffure pour Dames. Multitud reunida para asistir al
rapado de las mujeres acusadas de colaboración con los alemanes, Burdeos, 1944.

Imagen 4. Dos hombres rapan a una mujer acusada de colaboración, Burdeos, 1944.
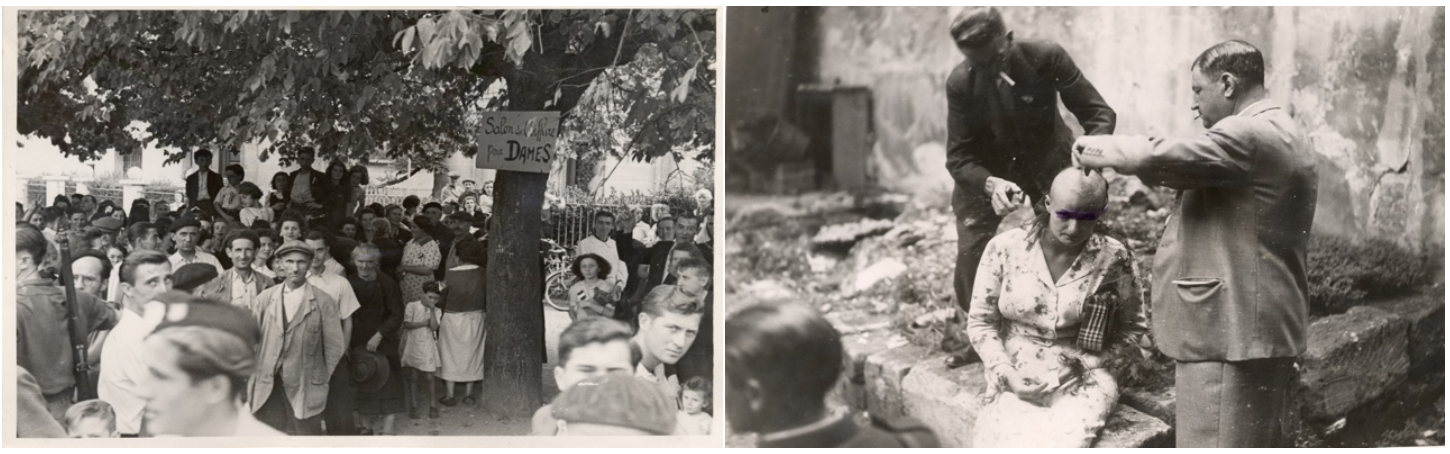

Fuente: ABM. 21Fi225 y ABM. 21Fi226

En efecto, "no se trataba tan solo de una actitud demasiado independiente, de una sexualidad extraconyugal prohibida para las mujeres, sino de una traición" ${ }^{111}$, de un delito de adulterio con los enemigos de la nación. Además, aquellas mujeres habían atentado contra el honor del varón, habían puesto en entredicho la autoridad del hombre francés sobre las mujeres y, por tanto, no era sino a través de sus cuerpos en el espacio público, como aquel poder tenía que ser recuperado. Así, "moral y política se unieron para despojar a las mujeres de su propio cuerpo", para recordarles que su cuerpo no les pertenecía $^{112}$. Gracias a los estudios de Alain Brossat y Fabrice Virgilli ${ }^{113}$ conocemos bien el procedimiento y las lógicas de género de aquel carnaval moche ${ }^{114}$, como lo denominaría Brossat. Y es que fueron aproximadamente 20.000 las mujeres rapadas en

\footnotetext{
${ }^{110}$ Robert Gildea, Marianne in Chains...op. cit., p. 73-75

${ }^{111}$ Fabrice Virgili, "Les tondues à la Libération: le corpos des femmes, enjeu d'une réaproppriation", Clio. Femmes, Genre, Histoire, 1, (1995), [En línea]. Consultado el 30 de abril de 2019. URL: http://journals.openedition.org/clio/518. Cita en página 4.

${ }^{112}$ Fabrice Virgili, "Les tondues à la Libération...op. cit., p. 4.

113 Alain Brossat, Les tondues. Un carnaval moche. Levallois-Perret, Editions (Manya, 1992). Fabrice Virgili, La France "virile". Des femmes tondues à la Liberation. Payot, (Paris, 2000). Asimimso, véase: Françoise Leclerc y Michèle Weindling, "La répression des femmes coupables d'avoir collaboré pendant l'Occupation", Clio. Femmes, Genre, Histoire, 1, (1995) [En línea], consulado el 30 de abril de 2019. URL: http://journals.openedition.org/clio/519

114 Podría traducirse como un "carnaval macabro".
} 
Francia entre 1943 y 1946, aunque la prensa clandestina ya desde 1942 animó al rapado de las colaboradoras ${ }^{115}$.

Esta otra cara de la Liberación hizo reflexionar a Conchita sobre la condición humana y la frontera que separaba a un colaborador de un superviviente en tiempo de guerra y Ocupación. El miércoles 22 de noviembre de 1944 escribió en su diario: “(...) Dicen que en dichos barrios hay alemanes escondidos y hay franceses que les suministran alimentos. Sin duda, antiguos colaboradores o ¿quién sabe? Ser humano no es pecado" 116 . Menos de un mes después supo del fusilamiento por colaboración del hermano de una amiga suya, y anotó: "Sus padres son muy buenas personas, pero la guerra y el miedo acobardan y cambian a las gentes honradas, (...) A nosotros nos estiman mucho y compadecen nuestro drama, sin buscar más allá de la compasión"117. Y un cinco de enero de 1945 señaló: "He visto un camión lleno de prisioneros alemanes, la gente insultaba, y lo comprendo, pero yo no puedo alegrarme"118. Además, los rumores, las miradas y el control de comportamientos sospechosos que inundaron el día a día de la Liberación, también tuvieron su impacto en ella y en sus aspiraciones: "He dejado de estudiar alemán -lamentó un 22 de noviembre de 1944-, pues en la escuela nos miraban mal. Siento mucho esta situación y sobre todo olvidar un idioma que aprendí con tanta facilidad" ${ }^{119}$.

\footnotetext{
${ }^{115}$ Luc Capdevila, "Identités masculines et féminines...op. cit., pp. 199-220. Como señala Luc Capdevila en este mismo texto, estos eventos no fueron en absoluto aislados, y entre otros casos, los rapados de las republicanas españolas por los franquistas durante la guerra y la posguerra, eran recientes y cercanos.

${ }^{116}$ Conchita Ramírez, Diario de una niña exiliada...op. cit., pp. 113-114.

${ }^{117}$ Ibid., p. 114.

${ }^{118}$ Ibid., p. 116.

${ }^{119}$ Ibid., p. 114.
} 


\section{Imagen 5. Grupo de prisioneros alemanes detenidos por las fuerzas de Liberación, Place de la Comédie, Burdeos. Agosto 1944.}

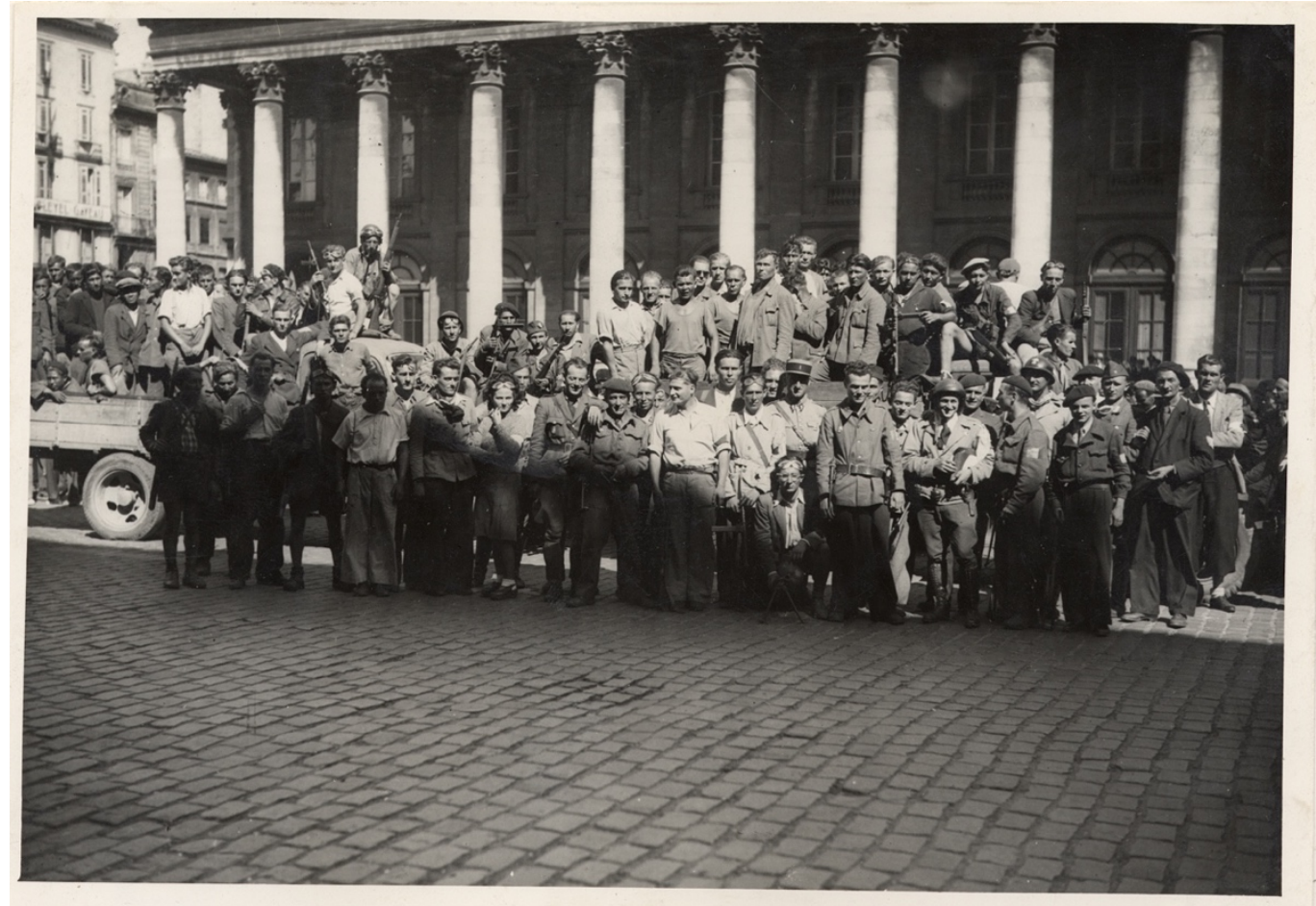

Fuente: ABM. 21Fi173

Durante la cohabitación con los ocupantes como durante la Liberación, la complejidad cotidiana de la experiencia vivida a ras de suelo hizo cuestionar los discursos articulados en clave dicotómica. Para Conchita no hubo blancos y negros, y la imagen del "enemigo" se construyó y se deconstruyó cada día. Más de 70 años después de aquello, tras conocer la crueldad sin límites del nazismo y ser la viuda de un internado en Auschwitz, seguía pensando lo mismo que dejó reflejado en su diario:

$Y$ alli estuve trabajando y los alemanes se comportaron conmigo maravillosamente. Y me contaban sus penas. Algunos me decian: "mis padres están en campos de concentración", que ellos son los primeros que van a los campos de concentración, los alemanes, eh. Y bueno, me querían mucho y, cuando expliqué mi situación y lo que pasaba, me decían...me saludaban: "buenos días, Pasionaria" (risas). Yo decía: "no se atrevan a decir eso porque me va a costar caro, verás". Pero se portaron muy bien. Claro, yo me pasaba con los alemanes en el trabajo desde las 8 de la mañana hasta las 8 de la noche. (...) Ahora no me acuerdo de mucho, pero tenía 
muchos recuerdos de los alemanes. Los alemanes se han portado muy bien conmigo ${ }^{120}$.

Como venimos señalando, en este contexto excepcional de Ocupación y, ahora también de Liberación, el género marcó profundamente las relaciones de poder que Conchita mantuvo con los alemanes y con aquellos que los habían combatido. La sexualidad fue una pieza fundamental de ellas, antes y después de 1944. Es más, la Liberación tuvo significativas contradicciones en materia de género, y es que al tiempo que se garantizó la emancipación política de las mujeres con su acceso a la ciudadanía, se las confinó más que nunca en el espacio doméstico ${ }^{121}$. La vuelta al orden implicaba también un retorno a los roles de género hegemónicos y esta dialéctica no solo interpeló a las mujeres francesas, sino también a las españolas que no tuvieron más remedio que rehacer sus vidas en suelo francés. Una argumentación que se vería, además, reforzada por la que mantuvieron los propios refugiados, quienes anhelaban profundamente la "normalización" de sus vidas cotidianas, después de su propia guerra, el exilio y la contienda mundial $^{122}$.

\section{REFLEXIONES FINALES}

En febrero de 1936 Conchita Ramírez comenzó a escribir un diario que hoy, más de ochenta años después, nos permite visitar a ras de suelo los años de la Ocupación de Francia desde la mirada y los sentimientos de una joven refugiada española. A lo largo de las páginas anteriores, hemos intentado poner de relieve que su experiencia de la Ocupación, lejos de inscribirse en categorías dicotómicas de opresión-resistencia, constituyó más bien un diálogo con las contradicciones, las ambigüedades y, en definitiva, con la complejidad cotidiana. A su vez, hemos subrayado su capacidad de acción y agencia, así como su habilidad para gestionar las relaciones de poder y las condiciones de opresión que la subordinaron, lo que implicaba contestarlas a veces y asumirlas otras muchas. En este sentido, Conchita, como otras muchas mujeres en aquel

\footnotetext{
${ }^{120}$ Entrevista realizada por Alba Martínez a Conchita Ramírez, 13-06-2016, Dos Hermanas, Sevilla.

${ }^{121}$ Luc Capdevila, "Identités masculines et féminines...op. cit.,pp. 200-201. Claire DUCHEN, Women's Right and Women's Lives in France 1944-1968, (Taylor \& Francis Group, 1994), p. 12.

122 En este sentido, véase: Elena Díaz Silva, Héroes, indeseables y vencidos. La quiebra y la reconstrucción del modelo de masculinidad republicano en el exilio mexicano, (Granada: Comares, 2019).
} 
momento, no fue una mera receptora de las lógicas del poder, sino que desde ellas se convirtió en un sujeto político capaz de sobrevivir en condiciones tan extremas y excepcionales. Hemos constatado, también, que el género fue un elemento constitutivo y significante de las relaciones que se entablaron con el ocupante, quizás en mucha mayor medida de lo que lo fue su condición de refugiada y extranjera, cuya identidad, sin embargo, se fue definiendo durante la experiencia de la Ocupación y, en particular, a raíz de sus conversaciones con el ocupante en el espacio laboral y de las humillaciones y la represión que observó desde el hogar y la comunidad.

Todo ello lo hemos podido advertir a través de un análisis estructurado a partir de los escenarios que, a nuestro entender, articularon la cotidianidad de nuestra protagonista bajo la Ocupación. El espacio laboral, lugar donde la cohabitación con el ocupante fue más estrecha, nos muestra relaciones de poder más fluidas, atravesadas por la profesionalidad y el respeto, por las experiencias de guerra y represión compartidas entre el ocupante y el ocupado y, especialmente, por la sexualidad, el amor y el cortejo. Desde el hogar y la comunidad, la experiencia de la Ocupación y las relaciones con los alemanes se vislumbran más rígidas y humillantes, lo que alimentó su posición de subordinación y vulnerabilidad que intentó ser contrarrestada a través de las redes de solidaridad y ayuda mutua tejidas entre los miembros que conformaron este espacio. Las calles de la ciudad de Burdeos, sus tranvías y sus cines fueron también espacios estructurantes de su vida cotidiana. Lugares que, si bien de un lado convirtieron al ocupante en omnipresente, también ofrecieron oportunidades para evadirse, divertirse y resistir. Por último, la Liberación, abordada aquí como epílogo de una Ocupación compleja, albergó, de nuevo, significativas contrariedades que, desde una perspectiva de género, inquietaron de nuevo a esta joven refugiada. Las imágenes de las purgas, de las rapadas y los prisioneros alemanes, del colaboracionista y el traidor, convivieron con la alegría, el jolgorio y los festejos por haber sido liberados. ¿Qué Ocupación para qué Liberación?, cabe preguntarse. Una Ocupación como una Liberación sin blancos ni negros, pero lejos de la equidistancia. Una Ocupación como una Liberación experimentada y mediada por su identidad de género y de refugiada española. Una Ocupación como una Liberación que se encargó entonces y nos permite ahora poner en entredicho los relatos dicotómicos y mitificados. Una Ocupación como una Liberación 
que, vista desde la complejidad de la vida cotidiana de una mujer, nos ayuda a ser visitantes más sensibles y cuidadosos con nuestro pasado más traumático.

Sin ánimo de generalizar la experiencia de Conchita Ramírez, ni de pensarla como paradigma de la refugiada española en Francia, el análisis de una fuente como su diario abre una ventana de posibilidades desde las que pensar las vivencias de las mujeres españolas refugiadas en Francia. Su diálogo con la complejidad cotidiana tiene la capacidad de problematizar la imagen de la refugiada española como una suerte de "presencia ausente", como "acompañante" y "víctima pasiva" de aquel conflicto, y en consecuencia, allana el terreno para pensarla como protagonista y constructora de su día a día. Sigamos transitando este camino.

\section{BIBLIOGRAFÍA}

Adámez, Guadalupe, "La escritura necesaria: el uso de la correspondencia en las Memorias y Autobiografías de los exiliados españoles", en Alejandra IBARRA (coord.), No es país para jóvenes, Instituto Valentín Foronda, 2012.

--, Gritos de papel. Las cartas de súplica del exilio español (1936-1945), Granada: Comares, 2017.

Agamben, Giorgio, Homo Sacer. El poder soberano y la vida nuda, Madrid: Pre-textos, 2006.

Alted, Alicia, "El exilio republicano español de 1939 desde una perspectiva de las mujeres". Arenal. 4-2, (1997), pp. 223-238.

--, La voz de los vencidos. El exilio republicano de 1939, Madrid: Madrid, 2005.

Aprile, Sylvie, "De l'exilé à l'exilée: une histoire sexuée de la proscription politique Outre-Manche et Outre-Atlantique sous le Second Empire", Le Mouvement Social, 4, (2008), pp. 27-38.

Bertin-Maghit, Jean-Pierre, "Le monde du cinema français sous l'Occupation ou 25 ans de questions aux archives", Vingtième Siècle. Revue d'histoire, n. 88, (2005), pp. 109-120.

Bertin, Célia, Femmes sous l'Occupation, Stock, Paris, 1993.

Billig, Michael, "El nacionalismo banal y la reproducción de la identidad nacional", Revista mexicana de sociología, 60-1, (1998), pp. 37-57.

Bood, Micheline, Les années doubles. Journal d'une lycéenne sous l'Occupation, Robert Lafont, 1974.

Brossat, Alain, Les tondues. Un carnaval moche. Levallois-Perret, Editions Manya, 1992. 
Butler, Judith, Cuerpos que importan. Sobre los límites materiales y discursivos del sexo, México D. F.: Paidós, 2002.

--, Mecanismos psíquicos del poder. Teorías sobre sujeción. Madrid: Cátedra, 2001.

Capdevila, Luc, "Identités masculines et féminines pendant et après la guerre", en Molin-Rotureau, Évelyn (dir.), 1939-1945: combats de femmes. Françaises et Allemandes, les oubliées de l'histoire, Autrement, Paris, 2001, pp. 199-220.

Chedaleux, Delphine, "Des jeunes femmes dans le cinema français sous l'Occupation: contradictions en noir et blanc", Nouveau Monde éditions, n.12, (2009), pp. 163173.

De Hoyos, Jorge, "La formación de la identidad del refugiado: los republicanos españoles en México, discursos, prácticas y horizontes de futuro", Laberintos, n.14, (2012), pp. 49-68.

--, "La historiografía sobre refugiados y exiliados políticos en el siglo XX: el caso del exilio republicano español de 1939”, Ayer, vol. 2, (2017), pp. 293-305.

Del Arco Blanco, Miguel Ángel, Hambre de siglos. Mundo rural y apoyos sociales del franquismo en Andalucía Oriental (1936-1951), Granada: Comares, 2007.

Diamond, Hanna, Women and the Second World War in France, 1939-1948. Choices and Constraints, New York, Routledge, 2013.

Díaz Silva, Elena, Héroes, indeseables y vencidos. La quiebra y la reconstrucción del modelo de masculinidad republicano en el exilio mexicano, Granada: Comares, 2019.

Diaz, Delphine, "Femmes en exil, femmes réfugiées dans la France du premier XIX siécle. Vers la difficile reconnaissance d'un statut", en Beaupré, Nicolas y Rance, Karine (dirs.), Arrachés et Déplacés. Réfugiés politiques, prisonniers de guerre et déportés, 1789-1918, Presses Universitaires Blaise Pascal, 2016, pp. 47-62.

Dombrowski Risser, Nicole, France under Fire. German Invasion, Civilian Fight, and Family Survival during World War II, New York: Cambridge University Press, 2012.

Dominguez, Pilar, "Ellas nos cuentan. Los relatos de vida en la historia del exilio republicano en México" en Llona, Miren Entreverse. Teoría y metodología práctica de las fuentes orales, Bilbao: Universidad de País Vasco, 2012, pp. 161-186.

--, De ciudadanas a exiliadas. Un estudio sobre las republicanas españolas en México, Madrid: Cinca, 2009.

Dreyfus-Armand, Geneviève, Septfonds 1939-1944. Dans l'archipel des camps français, Perpignan, Le Revenant éditeur, 2019.

Duchen, Claire, Women's Right and Women's Lives in France 1944-1968, Taylor \& Francis Group, 1994.

Duroux, Rose, "Historia y desmemoria: prácticas culturales en los refugios de mujeres españolas en Francia, 1939-1940”, Melanges Louis Cardillac, Zaghouan, 1995, FTERSI. 
Font i Agulló, Jordi y Gaitx Moltó, Jordi, "L'exili de 1939. Un estat de la qüestió entre dues commemoracions (2009-2014)", Franquisme \& Transició 2, (2014), pp. 231-280.

Gaspar Celaya, Diego, "Combatir sin armas. Mujeres españolas al servicio de la Francia Combatiente, 1940-1945”, Historia Social, 97, 2020, pp. 135-156.

Gildea, Robert, Marianne in Chains. In Search of the German Occupation 1940-1945, London: Macmillian, 2002.

Hernández Burgos, Claudio, "Tiempo de experiencias: el retorno de la Alltagsgeschichte y el estudio de las dictaduras de entreguerras", Ayer, 113, (2019), pp. 303-317.

Jackson, Julian, France. The Dark Years, 1940-1944, New York: Oxford University Press, 2001.

Jerram, Leif, Streetlife: The Untold History of Europe's Twentieht Century, Oxford: Oxford University Press, 2011.

Leclerc, Françoise y Weindling, Michèle, "La répression des femmes coupables d'avoir collaboré pendant l'Occupation”, Clio. Femmes, Genre, Histoire, 1, (1995).

Leruste, Florent, Juifs interés à Bordeaux (1940-1944): Le camp de MérignacBeaudésert, Les Éditions du Net, 2014.

Mahmood, Saba, "Teoría feminista y agente social dócil: algunas reflexiones sobre el renacimiento islámico en Egipto" en Suárez Navaz, Liliana y Hernández, Rosalva Aída (eds.), Descolonizando el feminismo. Teorías y prácticas desde los márgenes, Madrid: Cátedra, 2008, pp. 165-222.

Mancebo, M. Fernanda, "Las mujeres españolas en la Resistencia francesa", Espacio, Tiempo y Forma, v. 9, 1996, pp. 239-256.

Martínez, Alba, "Las mujeres recuerdan. Género y memoria sobre exilio republicano en Francia, 1939-1978”, Arenal. vol. 26, n. 2, (2019), pp. 367-398.

--, "Pour quelles raisons avez vous quitté l'Espagne? De represaliadas a refugiadas políticas en la Francia de los años 40 y 50", Historia Contemporánea, 59, (2019), pp. 277-314.

Maugendre, Maëlle, Femmes en exil. Les refugiées espagnoles en France, 1939-1942, Tours: Presses universitaires François-Rabelais, 2019.

--, Les réfugiées espagnoles en France (1939-1942): des femmes entre assujettissements et résistances. Tesis doctoral, Université Toulouse le MirailToulouse II, 2013.

Mcnay, Lois, Gender and Agency. Reconfiguring th Subject in Feminist and Social Theory, Cambridge: Polity Press, 2000.

Montenach, Anne, "Agency: un concept opératoire dans les études de genre? Introduction”, Rives méditerranéennes, 41, (2012).

Morelli, Anne (coord.), Femmes exilées politiques. Exhumer leur histoire, Buselas: Sextant, 2009. 
Moreno, Mónica, "L'exil au féminin: Républicaines et antifranquistes en France", en Vargas, Bruno (coord.), La Seconde Républicque Espagnole en exil en France (1939-1977), Presses Universitaires de Champollion, Albi, 2008, pp. 163-181.

--, “Las exiliadas, de acompañantes a protagonistas". Ayer, 81, (2011), pp. 265281.

Murillo, Irene, "Dignidad, supervivencia y luto. Agencia y resistencias de mujeres aragonesas de guerra y posguerra", en Yusta, Mercedes y Peiró, Ignacio (Coords.), Heterodoxas, guerrilleras y ciudadanas. Resistencias femeninas en la España moderna y contemporánea. Madrid: Institución Fernando el Católico, 2015, pp. 149-174.

Negrete, Rocío, "No tenía pretensiones, solo quería trabajar. Españolas en Francia, servicio doméstico y empleo informal (1939-1975)", Cahiers de civilisation espagnole contemporaine, 21, (2008).

Ortega, Francisco A., "Rehabitar la cotidianidad", en Francisco A. ORTEGA (ed.), Veena Das. Sujetos de dolor, agentes de dignidad, Bogotá: Universidad Nacional de Colombia, 2008, pp. 15-38.

Pallol, Ruben, "La lucha por la calle. Conflictos en la redefinición del espacio público en las ciudades de comienzos del siglo XX”, Crisol, 5, (2019), pp. 1-34.

Pérez-Olivares, Alejandro, "Vigilar y controlar. Espacio público, espacio privado y violencia en el Madrid ocupado (1938-1940)", en Román, Gloria y Santana, Juan Antonio (coords), Tiempo de dictadura. Experiencias cotidianas durante la guerra, el franquismo y la democracia, Granada: Editorial Universidad de Granada, 2018, pp. 67-89.

Lejeune, Philippe "Un journal à soi: historia de una práctica", Intramuros, (2005).

Polletta, Francesca, "Free spaces in collective action", Theory and Society, 28-1, (1999), pp. 1-38.

Ramírez, Conchita, Diario de una niña exiliada, 1939-1947, Sevilla: Diputación de Sevilla, 2006.

Rodríguez Barreira, Óscar, Migas con miedo. Prácticas de resistencia al primer franquismo. Almería, 1939-1953, Almería: Universidad de Almería, 2008.

Rodríguez Barreira, Óscar, "Lazarillos del caudillo. El hurto como arma de los débiles frente a la autarquía franquista", Historia Social, 72, (2012), pp. 65-87.

Román, Gloria, Delinquir o morir. El pequeño estraperlo en la Granada de posguerra. Granada: Comares, 2015.

Rygiel, Philippe, "Du genre de l'exil”, Le Mouvement Social, 4, (2008), p. 3-8.

Sauvé, Michaël, Le cinema de fiction durant l'Occupation: le rejet de la Révolution Nationale (1940-1945), Mémoire à la Maîtrise en Histoire, Université du Québec à Montreal, 2017.

Scott, Joan W., "El eco de la fantasía: la historia y la construcción de la identidad", Ayer, 62, (2006), pp. 111-138.

--, Género e Historia, México D.F.: UACM, 2008. 
Scott, James C., Los dominados y el arte de la resistencia, México D.F.: Txalaparta, 2003.

Schwartz, Paula , "The politics of food and gender in occupied Paris", Modern \& Contemporary France, Vol. 7, no 1 (1999), pp. 35-45.

Sebba, Anne, Les parisiennes. How the Women of Paris, Lived, Loved and Died in the 1940s, Londres, Weidenfeld \& Nicolson, 2016.

Sellier, Geneviève, "Gender studies et études filmiques", Cahiers du Genre, n. 38, (2005), pp. 63-85.

Shannon L. FOGG, The Politics of Everyday Life in Vichy France. Foreigners, Undesirables and Strangers, Nueva York: Cambridge University Press, 2009.

Simón Paula: "Los campos de concentración franceses contados por las mujeres: aportes para la reflexión sobre la narrativa testimonial femenina", Laberintos, n.14, (2012), pp. 151-165.

Steege, Paul et at, "The History of Everyday Life: A Second Chapter", The Journal of Modern History, vol. 80, n. 2, (2008), pp. 358-378.

Summerfield, Penny, Histories of the Self. Personal Narratives and Historical Practice, New York, Routledge, 2019.

Taliano-Des Garets, Françoise, "Bordeaux sous l'Occupation: collaboration, attentisme et résistance", Association pour la connaissance de l'Allemagne d'aujourd'hui, n²25, (2018), pp. 166-172.

Thébaud, Françoise y Dermenjian, Geneviève (dirs.), Quand les femmes témoignent. Histoire orale, histoire des femmes, memoire des femmes, Publisud, 2009.

Veillon, Dominique, "La vie quotidienne des femmes sous l'occupation” en MolinRotureau, Évelyn (dir.): 1939-1945: combats de femmes. Françaises et Allemandes, les oubliées de l'histoire, Autrement, Paris, 2001, pp. 32-48.

Vinen, Richard, The Unfree French. Life under the Occupation, London: Penguin Books, 2006.

Virgili, Fabrice, "Les tondues à la Libération: le corpos des femmes, enjeu d'une réaproppriation", Clio. Femmes, Genre, Histoire, 1, (1995).

--, La France “virile”. Des femmes tondues à la Liberation. Payot, Paris, 2000.

Walkowitz, Judith R., La ciudad de las pasiones terribles, Madrid: Cátedra, 1992.

Yusta, Mercedes, Madres coraje contra Franco, Madrid: Cátedra, 2009. 